\title{
Impacts of Deepwater Horizon oil and associated dispersant on early development of the Eastern oyster Crassostrea virginica
}

\author{
Vignier J. ${ }^{1,2}$, Donaghy L. ${ }^{1}$, Soudant $\mathrm{P}_{\dot{4}}{ }^{2}$, Chu F. L. E. ${ }^{3}$, Morris J. M. ${ }^{4}$, Carney M. W. ${ }^{4}$, Lay C. ${ }^{4}$, \\ Krasnec M. ${ }^{4}$, Robert Rene ${ }^{5}$, Volety A. K. ${ }^{1,}$
}

${ }^{1}$ Florida Gulf Coast Univ, Coll Arts \& Sci, Dept Marine \& Ecol Sci, Ft Myers, FL 33965 USA.

2 IUEM UBO, Technopole Brest Iroise, Lab Sci Environm Marin UMR LEMAR 6539, F-29280 Plouzane, France.

${ }^{3}$ Virginia Inst Marine Sci, Coll William \& Mary, Dept Aquat HIth Sci, Gloucester Point, VA 23062 USA.

${ }^{4}$ Abt Associates Inc, Boulder, CO 80302 USA.

${ }^{5}$ IFREMER, Unite Littoral, Ctr Bretagne, F-29280 Plouzane, France.

*Corresponding author : A. K. Volety, email address : voletya@uncw.edu

\begin{abstract}
:
The explosion of the Deepwater Horizon (DWH) oil platform resulted in large amounts of crude oil and dispersant Corexit 9500A® released into the Gulf of Mexico and coincided with the spawning season of the oyster, Crassostrea virginica. The effects of exposing gametes and embryos of $C$. virginica to dispersant alone (Corexit), mechanically (HEWAF) and chemically dispersed (CEWAF) DWH oil were evaluated. Fertilization success and the morphological development, growth, and survival of larvae were assessed. Gamete exposure reduced fertilization (HEWAF: EC20 ${ }_{1 \mathrm{~h}}=1650 \mu \mathrm{g} \mathrm{tPAH50} \mathrm{L^{-1 }}$; CEWAF: $\mathrm{EC}_{20} \mathrm{~h}=19.4 \mu \mathrm{g}$ tPAH50 L ${ }^{-1}$; Corexit: $\left.\mathrm{EC} 20_{1 \mathrm{~h}}=6.9 \mathrm{mg} \mathrm{L}^{-1}\right)$. CEWAF and Corexit showed a similar toxicity on early life stages at equivalent nominal concentrations. Oysters exposed from gametes to CEWAF and Corexit experienced more deleterious effects than oysters exposed from embryos. Results suggest the presence of oil and dispersant during oyster spawning season may interfere with larval development and subsequent recruitment.
\end{abstract}

\section{Highlights}

- C. virginica gametes and embryos were exposed to oil and/or Corexit for $96 \mathrm{~h}$. Adverse effects occurred during fertilization and early development. At equivalent nominal concentrations, CEWAF (oil+Corexit) and Corexit alone induced similar toxic responses to early life stages. Presence of oil and dispersant during oyster spawning season may interfere with subsequent recruitment.

Keywords : Deepwater Horizon oil, Oyster, Fertilization, CEWAF, Corexit, PAH 
3 The Eastern oyster, Crassostrea virginica (Gmelin, 1791), is one of the most commercially and ecologically important shellfish species propagating along the East Coast of the United States, from Maine to the Gulf of Mexico (Galtsoff, 1964; Volety et al., 2014). In 2012, total landings of $C$. virginica represented a value of \$104 million in the United States from which $\$ 74$ million originated in coastal regions of the northern Gulf of Mexico (National Marine Fisheries Service, 2012). In addition to its economic value, $C$. virginica is also an ecologically vital species. Oyster reefs, which have been built through successive reproduction and settlement of larvae onto existing reef structure, provide food, shelter, and habitat for many fish and shellfish species; improve water quality; stabilize bottom areas; and influence water circulation patterns within estuaries (Coen et al., 2007; Newell, 2004; Peterson et al., 2003; Volety et al., 2014; Wells, 1961). In the northern part of the Gulf of Mexico, the oyster spawning season typically occurs from mid-spring through late fall (Ingle, 1951). On April 20, 2010, the explosion of the Deepwater Horizon (DWH) oil platform in the Louisiana (McNutt et al., 2012). The oil leak was discovered two days after the incident at a depth of $1544 \mathrm{~m}$. After almost three months and several attempts to stop the leak, the well was finally cemented on July 15, 2010 (Crone and Tolstoy, 2010). Approximately 7 million L of the chemical dispersant Corexit $9500 \mathrm{~A}^{\circledR}$ were used directly at the wellhead and at the surface to disperse the oil slicks (Kujawinski et al., 2011). The DWH oil contaminated first the Louisiana coast and then the Mississippi, Alabama, and Florida coasts (Rosenbauer et al., 2010).

Petroleum hydrocarbon contaminants pose a severe ecological risk to marine origanisms. They can affect organisms by physical action (light reduction, asphyxia), by modification of habitat [change in pH (Neff, 1987), decrease of dissolved oxygen, decrease in food availability], and by toxic effects. Crude oil constituents are of particular concern because of their high chemical stability, low degradation, and lipophilic nature. Most toxic effects of crude oil are typically attributed to the aromatic fraction, particularly polycyclic aromatic hydrocarbons (PAHs); PAHs are known to be persistent in the environment and are potentially mutagenic, genotoxic, and carcinogenic to organisms (Albers and Loughlin, 2003; Neff, 1985; Roesijadi et al., 1978). 
1 Chemical dispersants are complex mixtures, primarily containing surfactants (dioctyl sodium sulfosuccinate, also known as DOSS) and solvents (propylene glycol), which reduce the interfacial tension at the oil-water interface, and therefore facilitate the mixing of oil into the water (Canevari, 1973; Li and Garrett, 1998). Therefore, oil slicks can be dispersed to concentrations below toxicity thresholds for most marine and benthic species (Lessard and DeMarco, 2000; Page et al., 2000) and become more accessible to hydrocarbon-degrading bacteria (Venosa and Zhu, 2003). Because of the higher exposure of aquatic organisms to petroleum compounds in coastal areas and estuaries, the manufacturer recommends using chemical dispersants at a minimum water depth of $20 \mathrm{~m}$, with a current speed greater than 1 $\mathrm{m} \mathrm{s}^{-1}$, and at a minimum distance from the shore or from off-shore islands of $2 \mathrm{~km}$ (Ramachandran et al., 2004). According to manufacturers, new dispersants, such as Corexit $9500 \mathrm{~A}^{\circledR}$, are considered non-toxic and bio-degradable when used on their own and at recommended concentrations. However, aquatic organisms are likely to be exposed to both dispersant and oil in combination, which may alter the toxic effects (Almeda et al., 2013; Barron et al., 2003; Getter and Baca, 1984; Gulec et al., 1997; Ramachandran et al., 2004; Rico-Martinez et al., 2013). Moreover, little is known about the behavior and combined effects of oil and dispersants in the near-shore environment (Allen, 1984).

The prolonged turbulent mixing of crude oil by wind, currents, and waves results in the production of water accommodated fraction (WAF) (Barron et al., 1999; Rossi et al., 1976). WAF toxicity is commonly assessed by measuring early larval growth, survival, and morphological abnormality in marine organisms such as fish (Couillard et al., 2005), starfish (Davis et al., 1981), crustaceans (Cucci and Epifanio, 1979), or bivalves (Fucik, 1994; SacoAlvarez et al., 2008). Early life stages are typically more sensitive than adult stages and represent a critical period in the life cycle (Chapman and Long, 1983; Connor, 1972; His and Beiras, 1999; Huffman Ringwood, 1991).

In an aquatic ecosystem, the physiological and ecological effects of environmental stress are numerous. Although the ultimate effect is mortality, sub-lethal effects include the alteration of normal physiological activities (Beiras and His, 1994; His and Robert, 1985) and increased expenditure of energy reserves affecting fecundity, as well as reduced fertilization success and larval viability and growth (Capuzzo, 1996; McDowell et al., 1999; Thompson et al., 1996). The Deepwater Horizon oil spill occurred at the beginning of the $C$. virginica spawning season. Sperm and eggs were therefore likely exposed to toxicants, as were adult and early life stage (ELS) of oysters. Research on the effects of Alaskan crude oil reported severe abnormalities in the developing embryos of Pacific oyster, Crassostrea gigas 
1 (Le Gore, 1974). PAHs, either alone or associated with sediments, as well as other organic 2 chemicals, negatively affected $C$. gigas sperm motility, embryonic development, larval 3 growth, and survival (Akcha et al., 2012; Geffard et al., 2002b, 2003; His and Robert, 1983;

4 Laramore et al., 2014; Lyons et al., 2002; Pelletier et al., 2000; Renzoni, 1975). Moreover, 5 the exposure of Pacific oysters to PAHs significantly reduced fertilization success and larval 6 development (Jeong and Cho, 2005). Finally, ELS of C. virginica were adversely affected by 7 acute exposure to dispersed oil (CEWAF), with decreased fertilization success $(\geq 100 \mathrm{ppm}$ 8 CEWAF) and increased developmental abnormalities ( $\geq 100$ ppm CEWAF) and mortalities $9 \quad\left(\right.$ LC50 $_{96 \mathrm{~h}}=24.8 \mathrm{ppm}$ CEWAF $)$ of D-larvae observed after incubation with a surrogate of Macondo oil dispersed with 1:10 of Corexit 9500A (Laramore et al., 2014). Therefore, fertilization success and subsequent embryogenesis and larval development of C. virginica might have been negatively affected by the exposure to oil, dispersed oil, and Corexit $9500 \mathrm{~A}^{\circledR}$, all of which were found in the Gulf of Mexico at the time of the spill. Although oysters have been used as a model organism in numerous ecotoxicological studies (Chapman and Long, 1983; Chapman, 1989; His et al., 1997; Thain, 1991, 1992; Woelke, 1972), little literature exists on the toxicity of dispersant and dispersed oil to $C$. virginica gametes and embryos; therefore, effects of these toxicants on fertilization success and early development need further investigation.

The purpose of this study was to examine the lethal and sub-lethal effects of acute exposure to surface-collected DWH oil (HEWAF), dispersant (Corexit $9500 \mathrm{~A}^{\circledR}$ ), or dispersed oil (CEWAF) on the two sensitive early life stages - gametes and embryos - of $C$. virginica. Fertilization success, morphological development, shell lengths, and survival were assessed at different time points ( $1 \mathrm{~h}, 24 \mathrm{~h}$, and $96 \mathrm{~h})$. In addition, lethal and sub-lethal concentration ranges were also determined. Research on the differences in gamete and embryo susceptibility to oil and dispersant may contribute to understanding the mechanisms of toxicity on sensitive early life stages of bivalves.

\section{Material and Methods}

Separate preliminary range-finding tests were performed to establish the definitive test concentrations that cause lethal effects on oyster gametes and embryos, as well as sub-lethal effects, such as developmental abnormalities and reduced growth of gametes and embryos. 
1 Exposure designs were based on standardized protocols described in "U.S. EPA. 1996.

2 Ecological Effects Test Guidelines: OPPTS 850.1055: Bivalve Acute Toxicity Test (embryo

3 larval)."

\subsection{Water Accommodated Fractions}

Crude oil was obtained from Stratus Consulting under chain of custody during the Deepwater Horizon NRDA efforts. The DWH surface slick oil ("Slick A") was collected near the source on July 29, 2010, from the hold of barge number CTC02404, which received surface slick oil from various skimmer vessels near the Macondo well (sample CTC02404-02). The dispersant Corexit 9500A ${ }^{\circledR}$ (NALCO Environmental Solutions LLC, Sugarland, TX) was obtained from Stratus Consulting / Abt Associates. For all exposure solutions, we added contaminants to UV-sterilized and $0.1 \mu \mathrm{m}$-filtered seawater (FSW), maintained at a salinity of 20-25 PSU.

\subsubsection{HEWAF}

The oil-only exposure solutions or high energy water accommodated fractions (HEWAFs) were prepared at $25^{\circ} \mathrm{C}$ under fluorescent lights to avoid photo-reactivity (Landrum et al., 1987). We artificially recreated the action of waves and currents by adding 2 L of filtered seawater (FSW) and $4 \mathrm{~g}$ of slick oil (with a gastight syringe) to a stainless steel blender pitcher (Waring ${ }^{\mathrm{TM}} \mathrm{CB} 15$, Waring Commercial, Torrington, CT). After $30 \mathrm{~s}$ at the lowest blending speed, the solution was transferred to a 2-L aspirator bottle and left to settle for at least $1 \mathrm{~h}$ to separate the residual floating oil (Incardona et al., 2013). The bottom layer of the mixture (or accommodated fraction) was then carefully drained from the aspirator bottle and FSW was added to this stock to prepare dilutions for exposure treatments. We did not filter preparations, so dilutions contained particulate oil in addition to dissolved PAHs.

\subsubsection{CEWAF}

The oil/dispersant mixtures or chemically enhanced water accommodated fractions (CEWAFs) were also prepared at $25^{\circ} \mathrm{C}$ under fluorescent lights. Two grams of slick oil and $200 \mathrm{mg}$ of dispersant $(10: 1 \mathrm{v}: \mathrm{v})$ were added to an aspirator bottle filled with $2 \mathrm{~L}$ of FSW. Contaminants were added with a gastight syringe, and stirred at a vortex adjusted to $25 \%$ using a stirring rod and a magnetic stirrer for $18 \mathrm{~h}$. To allow for the separation of the solution from the residual floating oil, the oil and dispersant mixture was left to stand for $3 \mathrm{~h}$ prior to use and the stock solution (or accommodated fraction) was carefully drained. 
3 Dispersant exposure solutions were prepared as described for CEWAF above, except that no

oil was added and the mixture was not settled. The dispersant stock was collected by draining the aspirator bottle and, to obtain different exposure concentrations, the stock solution was diluted with FSW. Samples for DOSS concentrations became contaminated, so nominal dispersant concentrations were reported for these tests.

Nominal concentrations used for exposure to HEWAF, CEWAF, and dispersant, as well as corresponding tPAH50 contents, are listed in Table 1; PAH profiles of the stock solution of CEWAF and HEWAF are shown in Figure 1.

\subsection{Oyster broodstock conditioning}

Adult specimens of Crassostrea virginica (average weight of $75 \mathrm{~g} \pm 20$ ) were collected in June 2011 and in October 2013 from natural populations in the same general location in Estero Bay, Florida (Lat. 26 19'50' N, Long. 81 '50'15' W). Adult oysters were held in the experimental hatchery at $23^{\circ} \mathrm{C} \pm 1$, in a flow-through system supplied with coarsely filtered (30- $\mu \mathrm{m}$ sand filter) seawater, at ambient salinity (20-30 PSU), under natural light conditions, and fed a mixture of laboratory-cultured fresh microalgae (Chaetoceros sp., Tetraselmis chui, and Tisochrysis lutea) at a daily ration of 3\% of oyster dry body weight for conditioning (Utting and Millican, 1997). Ten oysters were periodically sampled and examined for ripeness under a microscope.

\subsection{Spawning and gamete recovery}

Gamete and embryo exposures to CEWAF and dispersant were performed with offspring obtained from the same stock of adult oysters, at the end of August 2011. HEWAF exposures were conducted in December 2013, with offspring obtained from different broodstock.

Mature oysters were thermally induced to spawn by alternating an immersion in seawater at $18^{\circ} \mathrm{C}$ and $30^{\circ} \mathrm{C}$ for $30 \mathrm{~min}$ each time. To collect oocytes, spawning females were isolated in 1-L beakers filled with about $500 \mathrm{~mL}$ of FSW. To obtain a dense sperm solution, spawning males were isolated in approximately $200 \mathrm{~mL}$ of FSW in 1-L beakers. Oocytes and sperm were examined under a microscope to select the best gametes; we particularly examined sperm for mobility and oocytes for shape and absence of atresia. After filtration through a 55$\mu \mathrm{m}$ mesh to remove debris, sperm from several males $(n \geq 3)$ was pooled in a 1 -L sterile 
beaker. Eggs from several females $(n \geq 3)$, after successive sieving through $150-\mu \mathrm{m}$ and 55$\mu \mathrm{m}$ mesh to remove tissue and debris, were rinsed in a $20-\mu \mathrm{m}$ sieve and transferred into a sterile beaker filled with $2 \mathrm{~L}$ of FSW. Five $50 \mu \mathrm{L}$ subsamples of FSW/egg mixture were taken from the beaker after continuous and gentle mixing. Subsamples of eggs were stained with 1\% Lugol and counted using a Sedgwick-Rafter ${ }^{\circledR}$ cell and a dissecting microscope.

\subsection{Acute exposure of gametes}

\subsubsection{Fertilization assay}

Before fertilization, sperm and oocytes were exposed separately to various concentrations of HEWAF, CEWAF, or dispersant for $30 \mathrm{~min}$ ( $\mathrm{n}=4$ replicates for each concentration) (Table 1). Controls consisted of exposure to FSW only. Each 10-mL replicate of sperm (dense solution of $1.5 \times 10^{7}$ to $2.5 \times 10^{7}$ cells $\mathrm{mL}^{-1}$ ) was incubated in the test solution $(40 \mathrm{~mL}$ HEWAF, CEWAF, or dispersant solution in 50-mL beakers). Oocytes $(4,000-4,400)$ were also incubated in the test solution (200 mL HEWAF, CEWAF, or dispersant in $400-\mathrm{mL}$ beakers).

After the 30-min incubation, oocytes from each exposure replicate were fertilized with $10 \mathrm{~mL}$ of sperm from corresponding sperm-exposure replicates. Fertilization beakers were maintained in darkness at $26 \pm 1{ }^{\circ} \mathrm{C}$ and at a salinity of $22 \pm 2 \mathrm{PSU}$ for $96 \mathrm{~h}$ (4 days). Each test chamber was subsampled 1 -h post-fertilization and samples were preserved in $10 \%$ buffered formalin for later examination. To determine fertilization success, at least 100 embryos per treatment were examined for cell cleavage.

\subsubsection{Embryogenesis and larval development}

The progress of embryogenesis and larval development was monitored after fertilization for $96 \mathrm{~h}$ and the exposure solutions were not renewed. Fresh cultured phytoplankton was added to each beaker at day $1\left(5 \times 10^{4}\right.$ cells $\left.\mathrm{mL}^{-1}\right)$ and day $3\left(1 \times 10^{5}\right.$ cells $\left.\mathrm{mL}^{-1}\right)$ post-fertilization. One day $(24 \mathrm{~h})$ and 4 days (96 h) after fertilization, a subsample was removed from each beaker and fixed in $10 \%$ buffered formalin for later examination of abnormalities and larval shell lengths (see Section 2.6 for more details). Exposures were completed after $96 \mathrm{~h}$.

\subsection{Acute exposure of embryos}

While the gametes were incubated in exposure solutions, the remaining unexposed oocyte solution (around 5 million eggs in $2 \mathrm{~L}$ ) was fertilized with $50 \mathrm{~mL}$ of the remaining unexposed 
1 sperm. Forty-five minutes later, the fertilization success was verified by microscopic examination using the same method as previously described in Section 2.4.1. Fertilized oocytes were then gently mixed with FSW, $50-\mu \mathrm{L}$ subsamples $(\mathrm{n}=5)$ were taken, and the number of fertilized oocytes was counted as previously described. One hour after fertilization, when the two- to four-cell stage was reached, embryos were transferred volumetrically using a micropipette into $400-\mathrm{mL}$ beakers filled with $200 \mathrm{~mL}$ of the different exposure concentrations of HEWAF, CEWAF, or dispersant (Table 1) (4 replicates per condition). Embryos were distributed at a targeted density of $\approx 20 \mathrm{~mL}^{-1}(4,000-4,400$ individuals per beaker) and incubated for $96 \mathrm{~h}$ in the dark at $26{ }^{\circ} \mathrm{C} \pm 1$ and 22 PSU \pm 2 . Freshly cultured phytoplankton (T. lutea) was added to each exposure beaker at day $1(5 \mathrm{x}$ $10^{4}$ cells $\left.\mathrm{mL}^{-1}\right)$ and day $3\left(1 \times 10^{5}\right.$ cells $\left.\mathrm{mL}^{-1}\right)$.

\subsection{Subsampling, final survival assessment, and measurements}

Twenty-four hour and $96 \mathrm{~h}$ after fertilization, a 5-10 $\mathrm{mL}$ subsample was collected from each exposure beaker and preserved with $10 \%$ buffered formalin for later observation of abnormalities and shell measurements. After $96 \mathrm{~h}$ of exposure, the content of each beaker was filtered through a $20-\mu \mathrm{m}$ nylon mesh and larvae were re-suspended in $20-\mathrm{mL}$ FSW. The final survival was assessed by taking $200-\mu \mathrm{L}$ subsamples $(\mathrm{n}=3)$ from the concentrate $(20 \mathrm{~mL})$ of each replicate and staining with 1\% Lugol. The remaining samples were preserved in 10\% buffered formalin for later observation of abnormalities and shell sizes at $96 \mathrm{~h}$. At each of the two sampling times, a minimum of 50 randomly selected individuals from each replicate were examined under a microscope to determine the percentage of normal, abnormal, and dead larvae; dead larvae had translucent, non-stained shells. Final survival of larvae was extrapolated from the number of larvae counted alive in the 96-h subsamples. To assess mortality, the extrapolated number of larvae counted alive was compared to the estimated number of larvae stocked at the test initiation. The percent fertilized and the volume of test mixture removed at earlier sampling time points were accounted for in the extrapolations. Categories of abnormal larvae included (Fig. 4): (1) segmented eggs, normal embryos, or malformed embryos that did not reach the D-larval stage; and (2) D-larvae with either a convex hinge, indented shell margins, incomplete shells, a protruded velum, or an extrusion of mantle (from His et al., 1997). In addition, at each sampling time, shell lengths of 25 randomly selected larvae from each beaker were measured under a microscope equipped with an ocular micrometer. 
Temperature, dissolved oxygen, salinity, and $\mathrm{pH}$ were measured daily using a Pro ODO optic probe (YSI), a refractometer, and a "Pinpoint" $\mathrm{pH}$ monitor (American Marine, Inc.), respectively. Total ammonia was measured at the start and the end of each exposure experiment using a Seal Analytical Auto Analyzer 3 and the G-171-96 method. Chemical analyses of the stock solutions, HEWAFs, CEWAFs, dispersant concentrations, and the FSW control were performed by ALS Environmental (ALS; formerly Columbia Analytical Services) and validated by Ecochem (Kelso, WA, USA). Polycyclic aromatic hydrocarbons (PAHs), including alkylated homologues, were determined by gas chromatography with lowresolution mass spectrometry using selective ion monitoring (GC/MS-SIM) and a sum of 50 different PAHs [tPAH50] were quantified (Fig. 1). The analytical procedure was based on EPA Method 8270D with the GC and MS operating conditions optimized for separation and sensitivity of the targeted analytes.

\subsection{Statistical analyses}

Dose-response curves were fitted with the $d r c$ package in R version 3.1.1 (2014) (Ritz and Streibig, 2005; Ritz, 2010) using log-logistic models and effect concentrations (ECx/LCx) were estimated. For binomial response variables (mortality, abnormality, and fertilization), we fitted a three-parameter log-logistic model and reported the profile-likelihood based on 95\% confidence intervals (Faraggi et al., 2003; U.S. EPA, 2013; Venzon and Moolgavkar, 1988) using the bbmle package (Bolker, 2013; R Development Core Team, 2014). Reported effect concentrations accounted for control responses.

In addition to fitting nonlinear curves, analyses of variance (ANOVA) were performed on fertilization success and shell lengths data to obtain lowest observed effective concentrations (LOECs). To characterize differences in toxicity among life stages tested (gamete vs embryos), two-way ANOVAs were also conducted on shell lengths data. Before ANOVA analysis, all percentage data were arcsine-square root transformed to improve normality. Normality (Shapiro-Wilk test) and homogeneity of variances (Levene's test) were checked using the SPSS ${ }^{\circledR} 19.0$ statistical package. When significant effects of treatment were found (ANOVA: $\mathrm{p} \leq 0.05$ ), post-hoc tests were performed. We used Tukey post-hoc tests unless data did not meet homogeneity of variances requirements. In those cases, we used Dunnet's T3 post-hoc tests. 


\section{3. Results}

2

3

4

5

6

7

8

16

\begin{tabular}{ccccc}
\hline \multicolumn{2}{c}{ HEWAF } & \multicolumn{2}{c}{ CEWAF } & Dispersant \\
\hline $\begin{array}{c}\text { Nominal } \\
\text { oil } \\
\left(\mathrm{mg} \mathrm{L}^{-1}\right)\end{array}$ & $\begin{array}{c}\text { Nominal } \\
\left(\mu \mathrm{g} \mathrm{L}^{-1}\right)\end{array}$ & $\begin{array}{c}\text { oil } \\
\left(\mathrm{mg} \mathrm{L}^{-1}\right)\end{array}$ & $\begin{array}{c}\text { tPAH50 } \\
\left(\mu \mathrm{g} \mathrm{L}^{-1}\right)\end{array}$ & $\begin{array}{c}\text { Nominal } \\
\text { Corexit } \\
\left(\mathrm{mg} \mathrm{L}^{-1}\right)\end{array}$ \\
\hline 0 & 0.008 & 0 & 0.008 & 0 \\
\hline 62.5 & 108.3 & 6.25 & 1.3 & 0.62 \\
\hline 125 & 198.1 & 12.5 & 3.3 & 1.25 \\
\hline 250 & 417.0 & 25 & 6.4 & 2.5 \\
\hline 500 & 839.4 & 50 & 14.2 & 5 \\
\hline 1000 & 1634.5 & 100 & 26.2 & 10 \\
\hline
\end{tabular}

\subsection{Water quality and analytical chemistry}

Temperature and salinity throughout the experiments ranged from 24.8 to $26.1^{\circ} \mathrm{C}$ and from 22 to $25 \mathrm{PSU}$, respectively. The $\mathrm{pH}$ averaged $7.8 \pm 0.5$ and dissolved oxygen never decreased below $6 \mathrm{mg} \mathrm{L}^{-1}$ or $90 \%$ saturation. For each tested concentration of HEWAF, CEWAF, and dispersant, total ammonia concentrations remained at safe levels $\left(0.21 \mathrm{mg} \mathrm{L}^{-1} \pm 0.095\right)$. The FSW used for the control contained very low levels of PAHs at background levels (tPAH50 = $\left.0.008 \mu \mathrm{g} . \mathrm{L}^{-1} \pm 0.01\right)$. The PAH composition of the HEWAF was similar to the CEWAF profile (Fig. 1).

Table 1: Range of nominal concentrations $\left(\mathrm{mg} \mathrm{L}^{-1}\right)$ used for HEWAF, CEWAF, and dispersant exposures and corresponding PAH content (in $\mu \mathrm{g} \mathrm{L}^{-1}=$ sum of 50 PAHs or tPAH50 analyzed by GC/MS-SIM). 


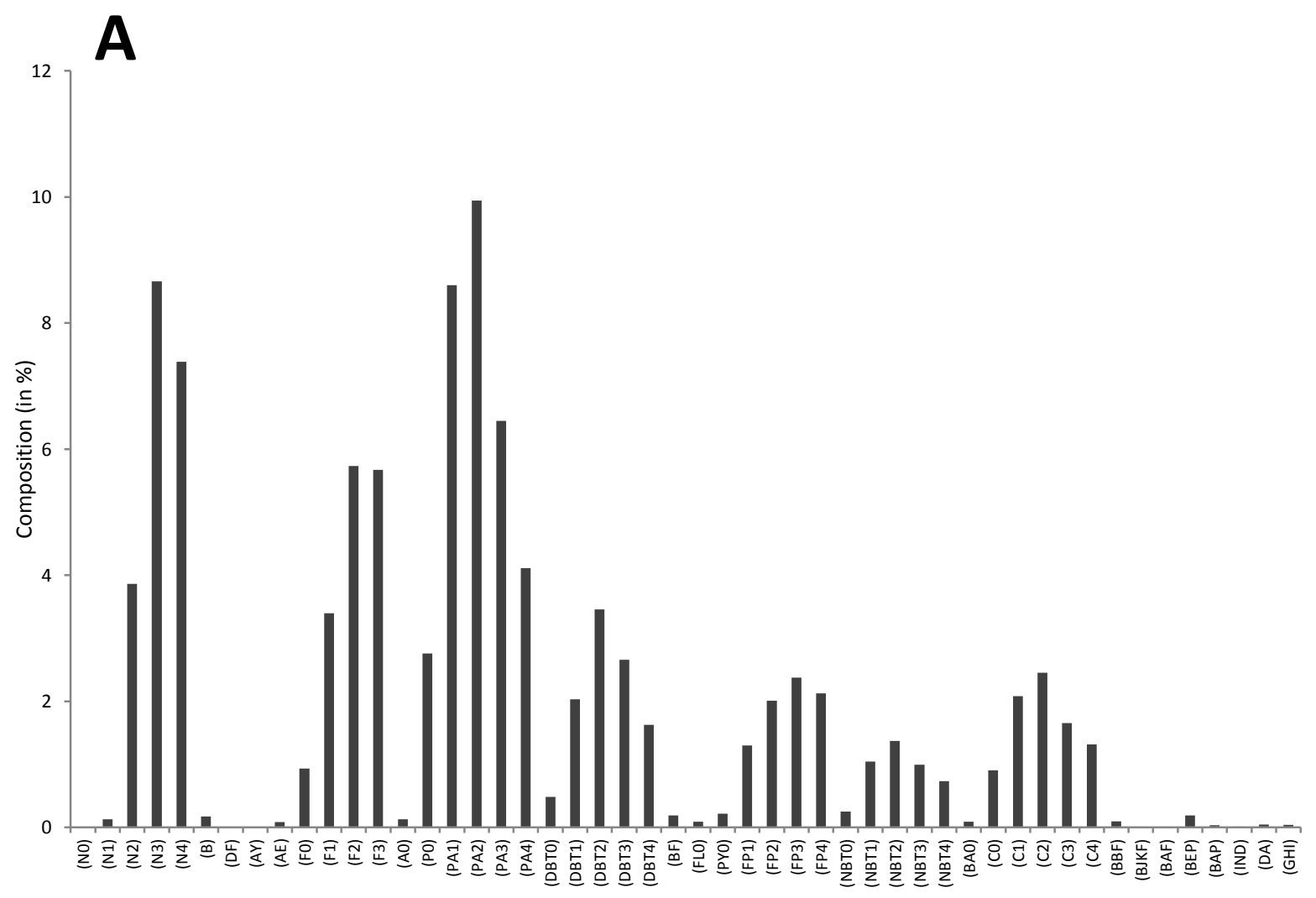

1

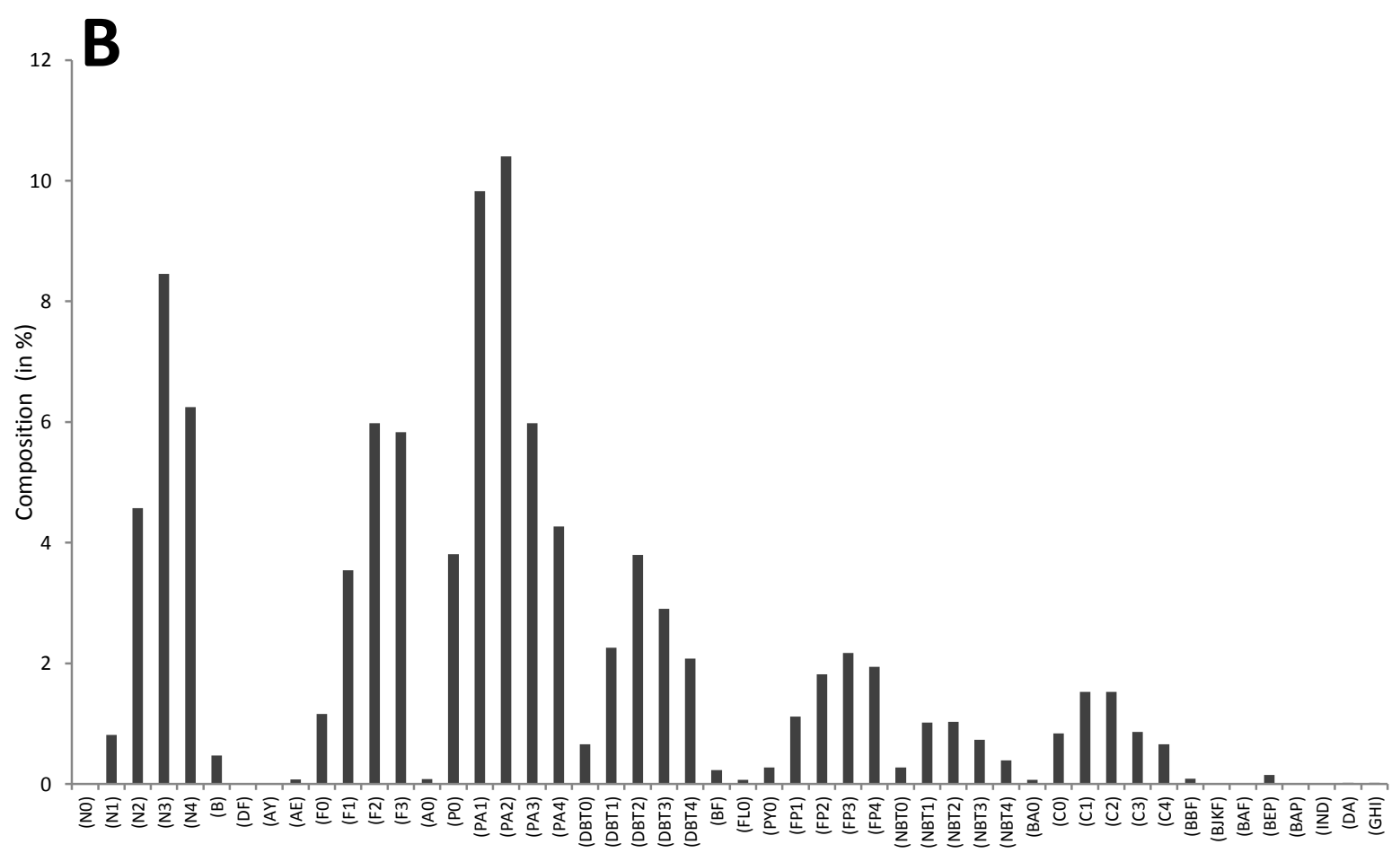

Figure 1: PAH composition of (A) HEWAF stock (2000 mg oil $\mathrm{L}^{-1}$ corresponding to $3209 \mu \mathrm{g}$ tPAH50 L-1) and (B) CEWAF stock $\left(1000 \mathrm{mg}^{-1} \mathrm{~L}^{-1}\right.$ corresponding to $262 \mu \mathrm{g}$ tPAH50 L-1) used for gamete and embryo acute exposure, expressed in percent. N0-4: Napthalene; B: Biphenyl; AY: Acenaphtylene; AE: Acenaphtene; F0-3: Fluorene; A0: Anthracene; PA0-4: Phenanthrene; DBT0-4: Dibenzothiophene; BF:Benzo(b)fluorine; FLO: Fluoranthene; PY0: Pyrene; FP1-4: 


\begin{tabular}{cccc}
\hline HEWAF & CEWAF \\
$\left(\mu \mathrm{g} \mathrm{tPAH} 50 \mathrm{~L}^{-1}\right)$ & $\left(\mu \mathrm{gtPAH} 50 \mathrm{~L}^{-1}\right)$ & $\begin{array}{c}\text { Dispersant } \\
\left(\mathrm{mg} \mathrm{Corexit} \mathrm{L}^{-1}\right)\end{array}$ \\
\hline \multirow{2}{*}{ EC20 } & $\mathbf{1 6 5 0}^{* * * *}$ & $\mathbf{1 9 . 4}$ & $\mathbf{6 . 9}$ \\
& $(1450-2050)$ & $(17.1-21.4)$ & $(6.3-7.6)$ \\
\hline \multirow{2}{*}{ EC50 } & $\mathbf{2 2 5 0}^{* * *}$ & $\mathbf{2 9 . 9}^{* * * *}$ & $\mathbf{1 1 . 5}^{* * *}$ \\
& $(1770-6460)$ & $(27.2-35.6)$ & $(10.2-12.7)$ \\
\hline
\end{tabular}

Fluoranthene/Pyrene; NBT0-4: Naphtobenzothiophene; BAO: Benz(a)anthracene; C0-4: Chrysene; BBF: Benzo(b)fluoranthene; BJKF: Benzo(j+k)fluoranthene; BAF: Benzo(a)fluoranthene; BEP: Benzo(e)pyrene; BAP: Benzo(a)pyrene; IND: Indeno(1,2,3)pyrene; DA: Dibenz(a,h)anthracene; GHI: Benzo(g,h,i)perylene. Parent compound is indicated by a 0 (e.g., N0); numbers of additional carbons for alkylated homologs are indicated as N1, N2, etc.

\subsection{Effects on fertilization}

Fertilization success was significantly reduced following exposure to oil/HEWAF $\left(F_{5,18}=\right.$ $10.8, p<0.001)$, dispersed oil/CEWAF $\left(F_{5,18}=23.1, p<0.001\right)$, or dispersant/Corexit $\left(F_{5,18}=\right.$ 19.7, $p<0.001$ ) for $30 \mathrm{~min}$ before fertilization (Fig. 2). Effective levels for fertilization inhibition (EC20 $1 \mathrm{~h}$ and $\mathrm{EC} 50_{1 \mathrm{~h}}$ ) are listed in Table 2. Fertilization success was inhibited by CEWAF and Corexit in a similar manner and at equivalent nominal concentrations. These results suggest that the dispersant is likely responsible for the majority of the fertilization inhibition observed in the CEWAF exposure (Fig. 2, Table 2).

Table 2: Concentration causing 20\% and 50\% inhibition (EC20/EC50) of fertilization success for gametes exposed for $1 \mathrm{~h}$ to HEWAF, CEWAF, and dispersant ( $\pm 95 \%$ confidence intervals). Data are

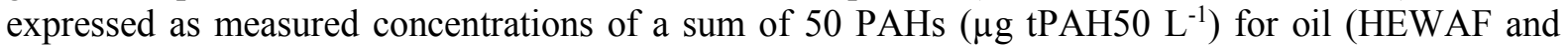
CEWAF) or nominal dispersant levels for Corexit $\left(\mathrm{mg} \mathrm{L}^{-1}\right)$.

${ }^{* * *}:$ the effect concentration exceeded the range tested. 

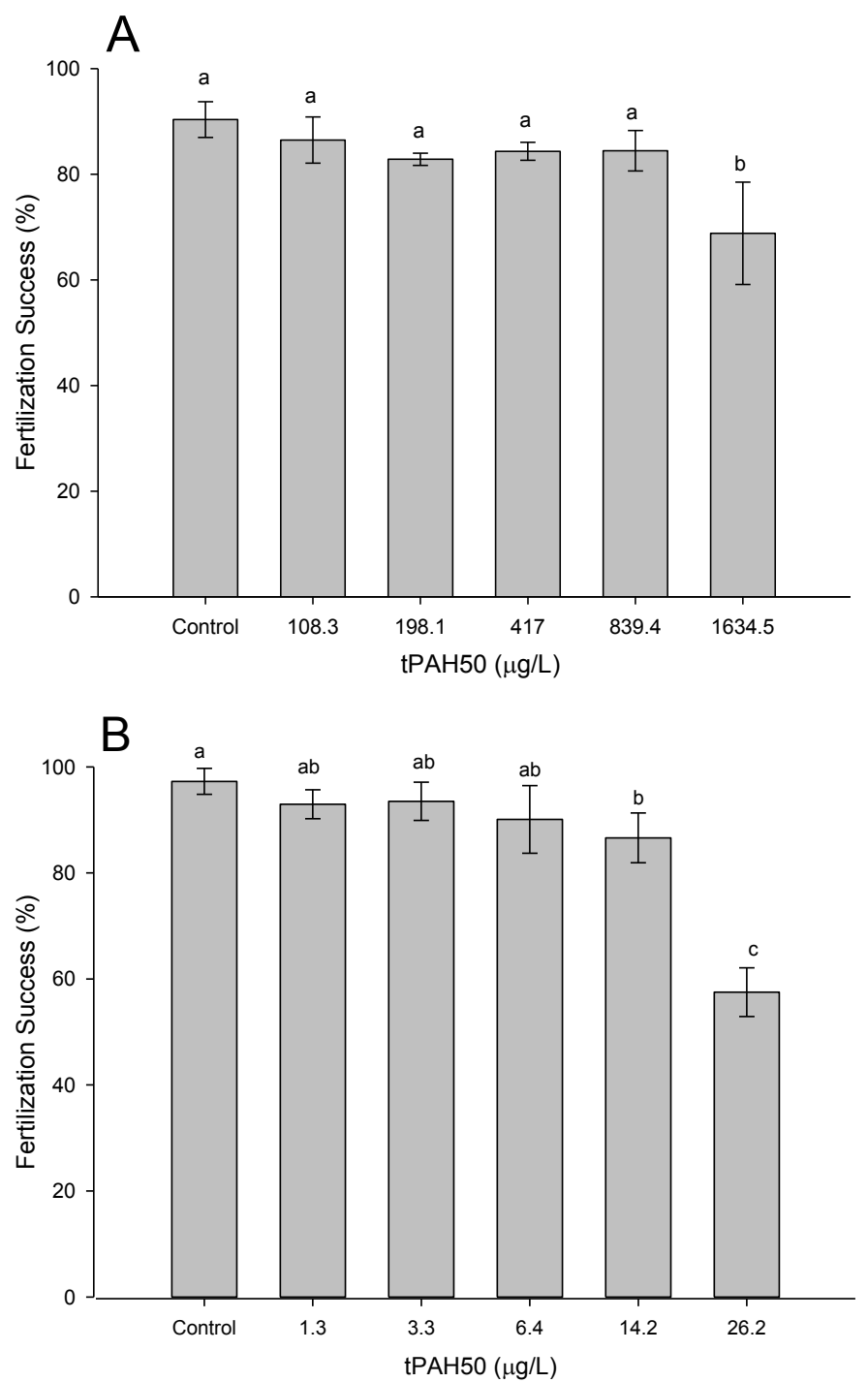

2

\section{C}

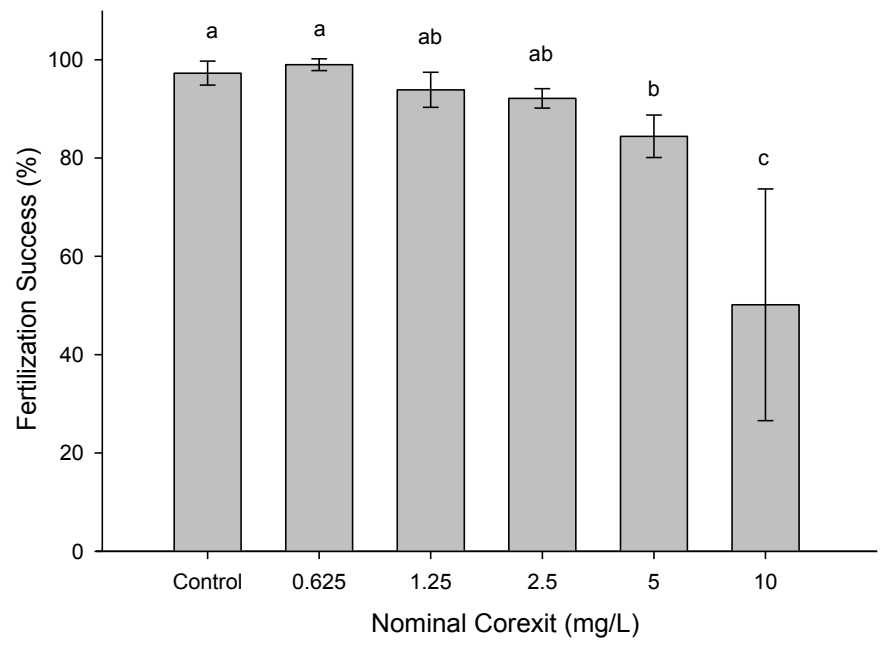

$4 \quad$ Figure 2: Fertilization success of $C$. virginica gametes (eggs and sperm) exposed to (A) high energy 5 water accommodated fraction (HEWAF), (B) chemically enhanced water accommodated fraction 6 (CEWAF), and (C) dispersant (Corexit $9500 \mathrm{~A}^{\circledR}$ ). Data are presented as mean percentage \pm standard 7 deviation (SD). Different letters denote a significant difference at $\mathrm{p} \leq 0.05$ (ANOVA, Tukey HSD post8 hoc test). 
4 Percentages of abnormal larvae in the controls were relatively low and ranged from 0 to $15 \%$.

5 Larval abnormalities increased with dose regardless of the exposure timing (Fig. 3). 6 Continuous exposure of gametes before fertilization until $24 \mathrm{~h}$ after fertilization to HEWAF, 7 CEWAF, or Corexit $9500 \mathrm{~A}^{\circledR}$ resulted in a dose-dependent increase in abnormal larvae (Fig. 8 3). In a similar way, the continuous exposure of newly segmented embryos for $24 \mathrm{~h}$ to all 9 HEWAF, CEWAF, and dispersant concentrations affected embryo and early larval development (Fig. 3). By comparing ECx values and their 95\% confidence limits for gamete and embryo exposure, with the exception of the CEWAF exposure (EC20 $24 \mathrm{~h}$, Table 3), abnormalities in $24 \mathrm{~h}$-old larvae resulting from gamete exposure were generally not statistically different from that of 24 h-larvae resulting from embryo exposure (Table 3, Fig. $3)$.

Oysters in the highest doses sometimes experienced too much mortality to be included in this analysis, although some of those mortalities may have been caused by abnormal development. High larval mortalities at the highest dose of dispersant tested in the gamete exposure did not allow the calculation of EC50 value (Table 3).

Table 3: Effective concentrations causing $20 \%$ and $50 \%$ of observed abnormality (EC20 \& EC50) in 1 day-old larvae previously exposed for $24 \mathrm{~h}$ to HEWAF, CEWAF and dispersant from gamete and embryo. Data are expressed as measured concentrations of a sum of 50 PAHs $\left(\mu \mathrm{g}\right.$ tPAH50 L $\left.{ }^{-1}\right)$ for oil (HEWAF and CEWAF) or nominal dispersant levels for Corexit $\left(\mathrm{mg} \mathrm{L}^{-1}\right) \pm 95 \%$ Confidence interval.

${ }^{* * *}$ : Effect concentration higher than 100\% lethal concentration. NC: Not Calculated

\begin{tabular}{|c|c|c|c|c|c|c|}
\hline Initial & & Gamete & & & Embryo & \\
\hline & $\begin{array}{c}\text { HEWAF } \\
\left(\mu \mathrm{g} \mathrm{tPAH} \mathrm{L}^{-1}\right)\end{array}$ & $\begin{array}{c}\text { CEWAF } \\
\left(\mu \mathrm{g} \mathrm{tPAH} \mathrm{L} \mathrm{L}^{-1}\right)\end{array}$ & $\begin{array}{c}\text { Dispersant } \\
\left(\mathrm{mg} \mathrm{L}^{-1}\right)\end{array}$ & $\begin{array}{c}\text { HEWAF } \\
\left(\mu \mathrm{g} \mathrm{tPAH} \mathrm{L} L^{-1}\right)\end{array}$ & $\begin{array}{c}\text { CEWAF } \\
\left(\mu \mathrm{g} \mathrm{tPAH} \mathrm{L} \mathrm{L}^{-1}\right)\end{array}$ & $\begin{array}{c}\text { Dispersant } \\
\left(\mathrm{mg} \mathrm{L}^{-1}\right)\end{array}$ \\
\hline EC20 & $\begin{array}{c}186 \\
(108-362)\end{array}$ & $\begin{array}{c}9.7 \\
(8.7-11.0)\end{array}$ & $\begin{array}{c}\text { 7.39 }^{* * * *} \\
(5.3-15.5)\end{array}$ & $\begin{array}{c}218 \\
(107-401)\end{array}$ & $\begin{array}{c}\mathbf{1 2 . 2} \\
(11.6-12.8)\end{array}$ & $\begin{array}{c}\mathbf{5 . 3} \\
(5.2-5.5)\end{array}$ \\
\hline EC50 & $\begin{array}{c}\mathbf{2 6 7} \\
(202-367)\end{array}$ & $\begin{array}{c}\mathbf{1 4 . 9}^{* * *} \\
(13-19.1)\end{array}$ & $\mathrm{NC}$ & $\begin{array}{c}\mathbf{3 4 2} \\
(242-504)\end{array}$ & $\begin{array}{c}\mathbf{1 5 . 6} \\
(14.9-16.5)\end{array}$ & $\begin{array}{l}\mathbf{5 . 6 7} \\
(\mathrm{NC})\end{array}$ \\
\hline
\end{tabular}


A

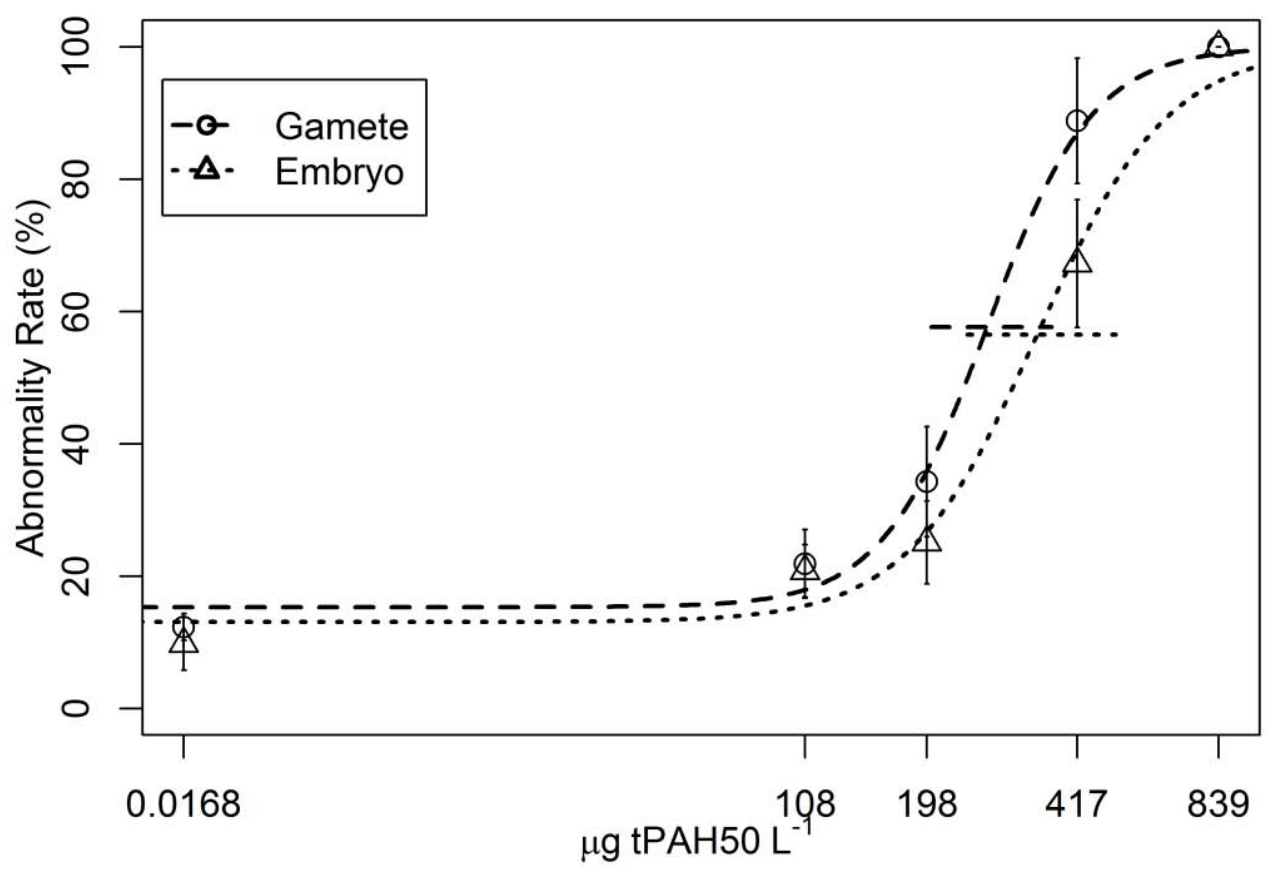

1

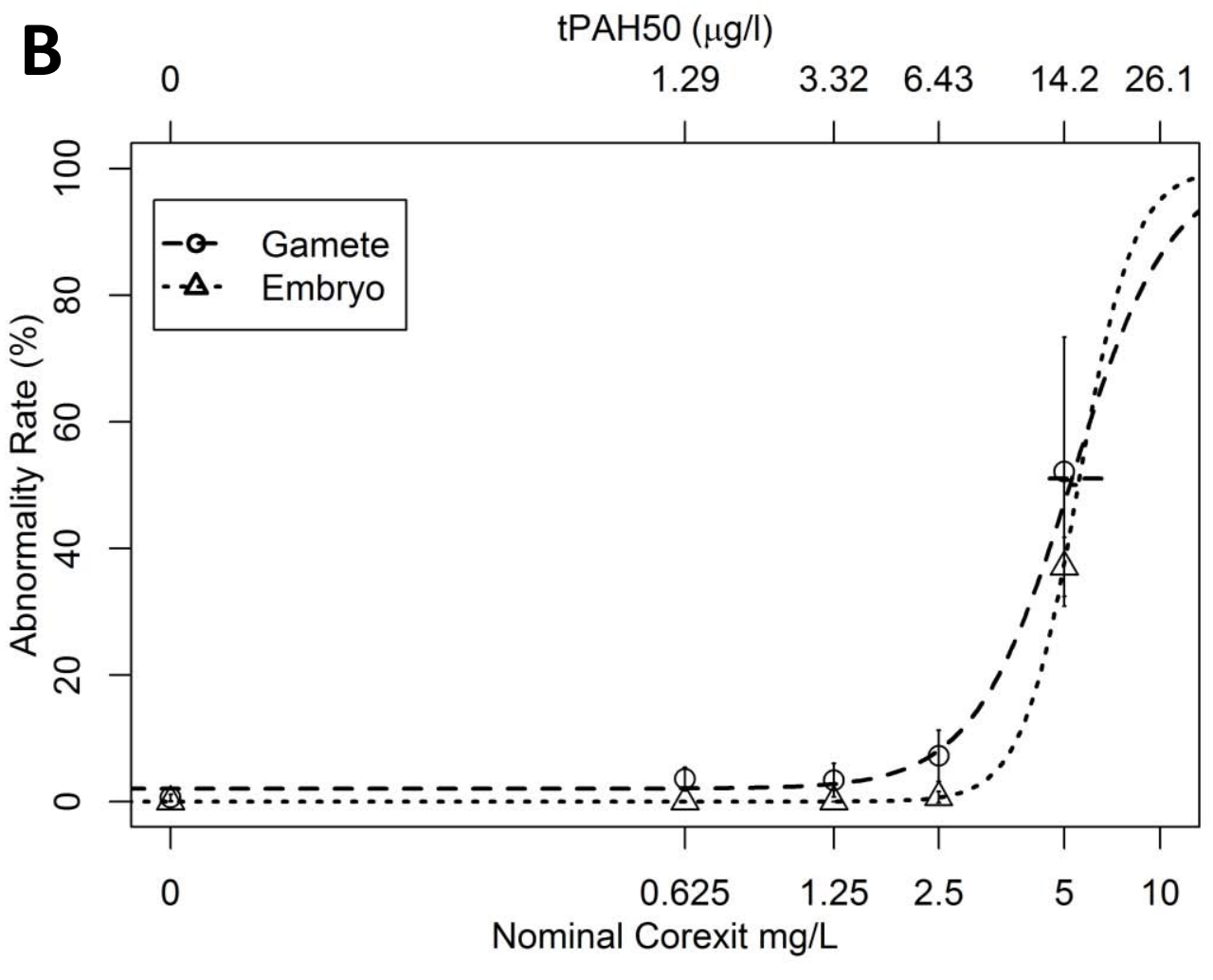




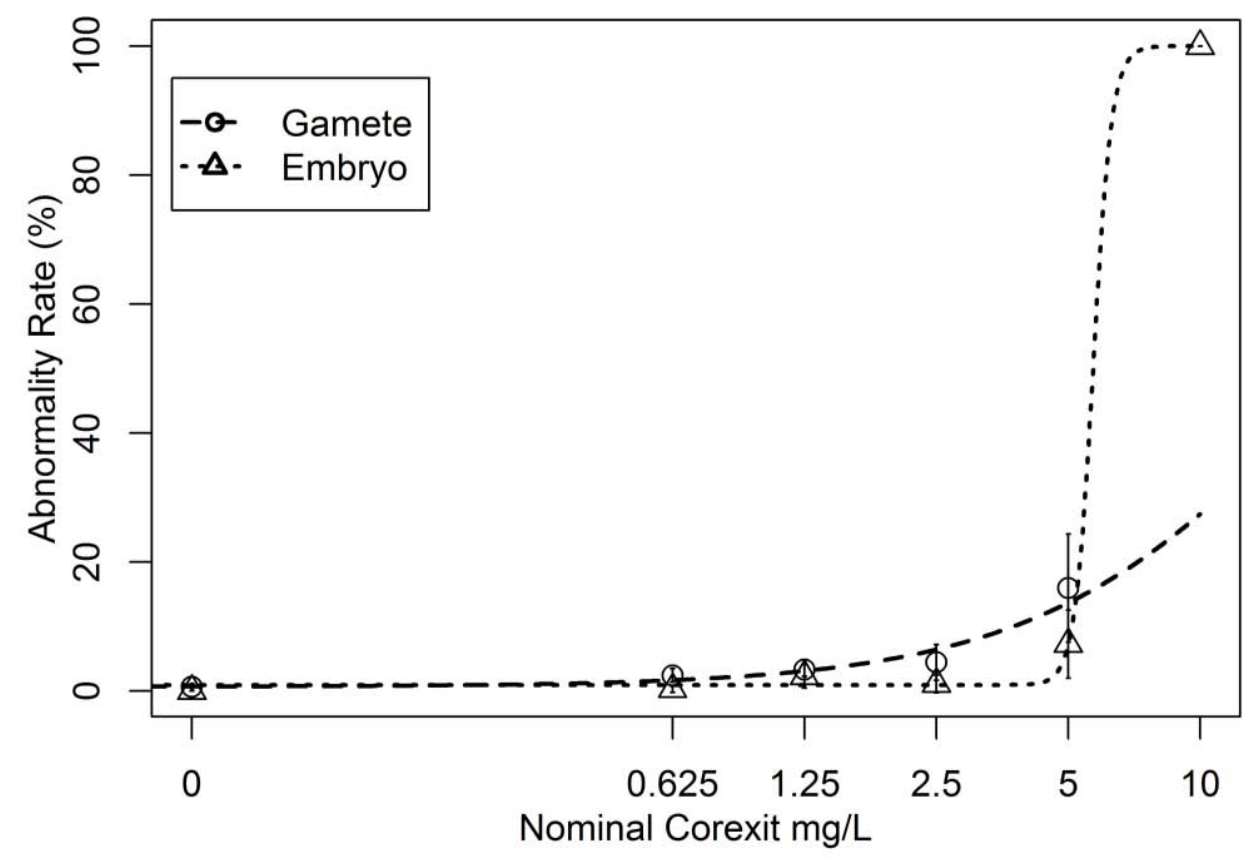

2 Figure 3: Mean percentages $( \pm \mathrm{SD})$ of abnormal larvae derived from gametes and embryos exposed to $3 \operatorname{HEWAF}(\mathrm{A}), \mathrm{CEWAF}(\mathrm{B})$, and dispersant (C) at 24-h post-fertilization. Horizontal lines on curves 4 represent $95 \%$ CI of EC50. In some high exposures, oysters died and disintegrated, and abnormality 5 rates could not be determined. Model for CEWAF abnormality (B) was fitted to tPAH50 exposure 6 concentration $\left(\mu \mathrm{g} \mathrm{L}^{-1}\right)$, and the corresponding nominal concentration of dispersant $\left(\mathrm{mg} \mathrm{L}^{-1}\right)$ is shown.

7

8 After $24 \mathrm{~h}$ of incubation with oil, visual observations revealed morphological abnormalities ranging from severely moribund to atrophied larvae (Fig. 4D), absence of shells, individuals with a convex-hinge, shell deformities (Fig. 4E), velums abnormally extended, incomplete shells and mantle extrusions (Fig. 4F), or indented shell margins.

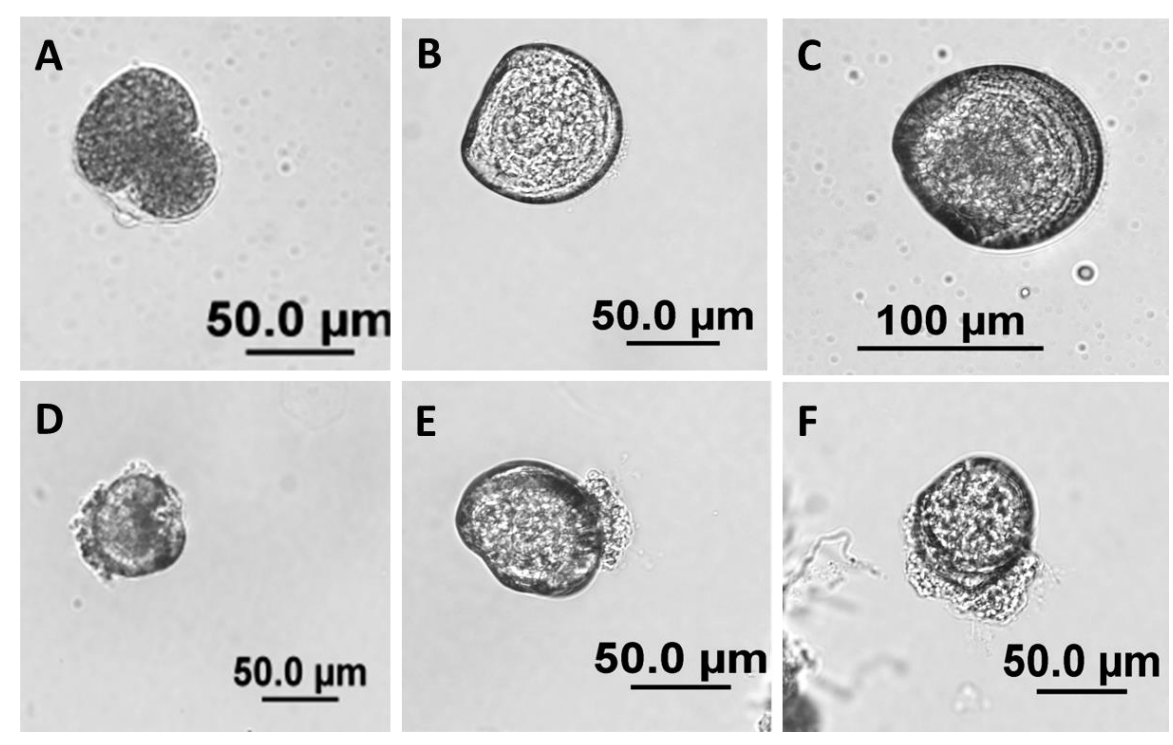


Figure 4: Normal embryo (A), normal 24-h-old (B), and normal 96-h-old larvae (C); abnormal larvae $(\mathrm{D}, \mathrm{E}, \mathrm{F})$ observed after $24 \mathrm{~h}$ exposure to HEWAF.

\subsection{Effects on larval size}

Control treatments showed an increase of mean shell lengths from 5 to $10 \mu \mathrm{m}$ over 3 days. Mean shell lengths of larvae exposed as gametes or embryos to CEWAF, HEWAF, or dispersant for 24 and $96 \mathrm{~h}$ consistently declined as exposure concentrations increased. Regarding exposure to HEWAF, the mean size of larvae derived from exposed gametes was significantly impaired at $198.1 \mu \mathrm{g}$ tPAH50 $\mathrm{L}^{-1}$ from $24 \mathrm{~h}$ onward $\left(F_{3,12}=54.2, p=0.024\right)$ (Fig. 5A), whereas the mean size of larvae developed from exposed embryos was inhibited significantly at $108.3 \mu \mathrm{g}$ tPAH50 $\mathrm{L}^{-1}$ compared to control $\left(F_{4,15}=58.3, p<0.001\right)$ (Fig. 5B). In addition, two-way ANOVA showed that the mean size of larvae exposed for $96 \mathrm{~h}$ from the embryo stage was significantly smaller than larvae exposed from the gamete stage $\left(F_{9,30}=\right.$ $8.1, p=0.008)$, possibly due to increased mortality in the gamete exposure.

After $24 \mathrm{~h}$ of exposure to all concentrations of CEWAF, means shell length of larvae developed from exposed gametes were significantly affected compared to the control $\left(F_{4,15}=\right.$ 45.7, $p<0.001$ ) (Fig. 5C). Concentrations as low as $1.3 \mu \mathrm{g}$ tPAH50 L $\mathrm{L}^{-1}$ significantly reduced the mean shell length of larvae exposed to CEWAF from the gamete stage $\left(F_{4,15}=45.7\right.$, $p=0.002$ ). However, even though $24 \mathrm{~h}$ exposure to CEWAF had a significant effect on the mean shell size of larvae exposed from embryos $\left(F_{4,15}=45.4, p<0.001\right)$, only the highest concentration (i.e. $14.2 \mu \mathrm{g}$ tPAH50 $\mathrm{L}^{-1}$ ) affected the mean shell lengths compared to the control $\left(F_{4,15}=45.4, p=0.012\right)$ (Fig. 5D). Regarding shell lengths measured after $96 \mathrm{~h}$ of exposure to CEWAF, similar trends to the $24 \mathrm{~h}$ exposure were observed for larvae derived from both exposed gametes and embryos (Fig. 5C and D). These results reflected an increase of sensitivity to CEWAF when exposure occurred before fertilization (e.g. embryos compared to gametes).

Corexit exposure induced a dose-response effect in shell length at $24 \mathrm{~h}$ and $96 \mathrm{~h}$ for larvae exposed from the gamete stage, with a LOEC value of $2.5 \mathrm{mg} \mathrm{L}^{-1}$ (Fig. 5E). No effect on the mean size of larvae, compared to the control, was observed after $24 \mathrm{~h}$ of exposure to dispersant from the embryo stage $\left(F_{4,15}=2.8, p=0.063\right)$, whereas mean shell lengths were significantly inhibited after $96 \mathrm{~h}$ of exposure to concentrations of $0.63 \mathrm{mg} \mathrm{L}^{-1}$ and above $\left(\mathrm{F}_{4,15}\right.$ 
$1=44.8, \mathrm{p} \leq 0.01)$ (Fig. 5F). The absence of data at the highest concentrations was due to high 2 mortalities.

3
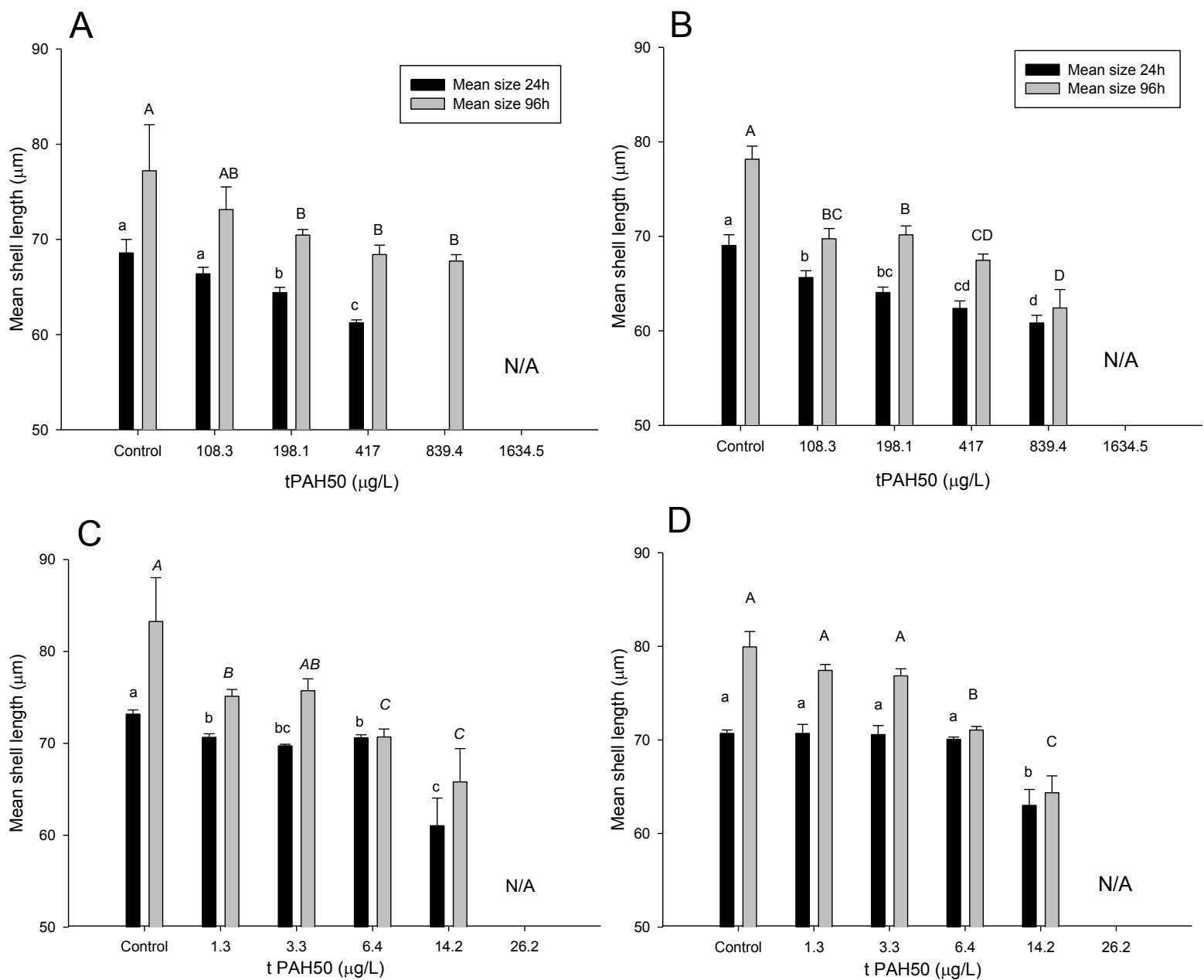

D
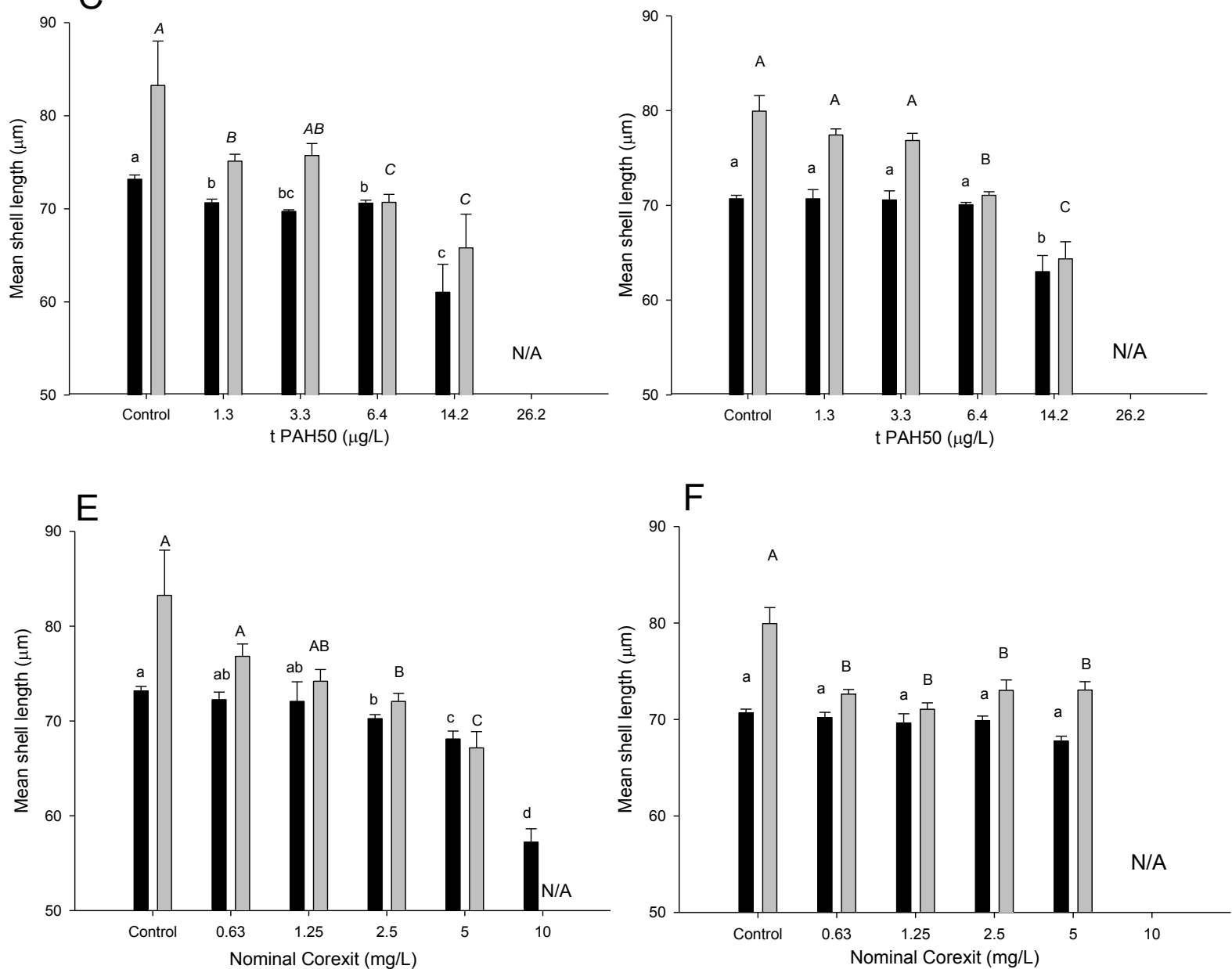

Figure 5: Mean shell lengths $(\mu \mathrm{m}) \pm$ standard deviation of larvae $(n=100)$ derived from gametes (eggs and sperm) and embryos exposed to $\operatorname{HEWAF}(\mathrm{A}, \mathrm{B}), \mathrm{CEWAF}(\mathrm{C}, \mathrm{D})$, and dispersant (E, F). Letters denote statistical difference at $\mathrm{p} \leq 0.05$ (ANOVA, Dunnett's post-hoc test). N/A: no live larvae were observed and/or measured. 
4 Mortalities for every exposed group were dose-dependent. In the highest concentrations, dead 5 larvae were noted with extruded and granulated tissues ("exploded" larvae). Compared to the

\subsection{Effects on survival after $96 \mathrm{~h}$}

control, HEWAF, CEWAF, and dispersant significantly reduced larval survival after $96 \mathrm{~h}$ exposure, regardless of whether the exposure occurred before or after fertilization (data not shown). According to the LC5096h values for CEWAF, larvae that were exposed as gametes were approximately twice as sensitive as larvae that were exposed as embryos (8.5 vs 17.7), suggesting an increase in tolerance to pollutants with age (Table 4). However, according to the LC5096h values for HEWAF exposures, larvae that were exposed as embryos were more sensitive than those that were exposed as gametes (220 vs 307) (Table 4). Values of LC5096h for Corexit exposure of embryos could not be calculated due to the high control mortality. For all exposures, it is important to mention that we accounted for the initial fertilization success in the LC5096h calculations.

Table 4: Concentrations causing 50\% mortality (LC50) of larvae exposed for $96 \mathrm{~h}$ to HEWAF, $\mathrm{CEWAF}$, or dispersant as gamete and embryo $( \pm 95 \% \mathrm{CI})$. Data are expressed as measured concentrations of a sum of 50 PAHs ( $\mu \mathrm{g}$ tPAH50 $\mathrm{L}^{-1}$ ) for oil (HEWAF and CEWAF) or nominal dispersant levels for Corexit $\left(\mathrm{mg} \mathrm{L}^{-1}\right)$. For the gamete test, non-fertilized eggs were accounted for by being subtracted from the total number.

NC: Not calculated (high control mortality).

\begin{tabular}{|c|c|c|c|c|c|c|}
\hline Initial Stage & & Gamete & & & Embryo & \\
\hline & $\begin{array}{c}\text { HEWAF } \\
(\mu \mathrm{g} \text { tPAH50 L-1) }\end{array}$ & 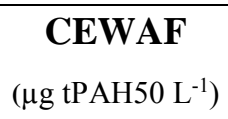 & $\begin{array}{c}\text { Dispersant } \\
\left(\mathrm{mg} \mathrm{L}^{-1}\right)\end{array}$ & 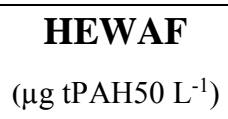 & $\begin{array}{c}\text { CEWAF } \\
\left(\mu \mathrm{g} \text { tPAH50 L }{ }^{-1}\right)\end{array}$ & $\begin{array}{c}\text { Dispersant } \\
\left(\mathrm{mg} \mathrm{L}^{-1}\right)\end{array}$ \\
\hline LC50 & $\begin{array}{c}\mathbf{3 0 7} \\
(303-312)\end{array}$ & $\begin{array}{c}\mathbf{8 . 5} \\
(8.4-8.7)\end{array}$ & $\begin{array}{c}\mathbf{2 . 7} \\
(2.6-2.8)\end{array}$ & $\begin{array}{c}\mathbf{2 2 0} \\
(216-224)\end{array}$ & $\begin{array}{c}17.7 \\
(17.5-17.9)\end{array}$ & $\mathrm{NC}$ \\
\hline
\end{tabular}

24

\section{Discussion}

The explosion of the Deepwater Horizon (DWH) oil platform on April 20, 2010, resulted in the largest marine oil spill in United States history (National Commission, 2011). This oil spill coincided with the spawning season of the eastern oyster, Crassostrea virginica. Because of their ecological importance, their filter-feeding activity, sessile nature, and ubiquity, oysters have been employed as a model organism in eco-toxicological studies and 
for bio-monitoring the marine environment. However, the information concerning the toxicity of crude oil, dispersed oil, and dispersant itself on $C$. virginica gametes and embryos is limited. A detrimental effect of the oil and the associated dispersants on the reproduction and early development of $C$. virginica could affect oyster recruitment and reduce natural stocks in the affected areas.

\subsection{Effects on fertilization}

Results of the present study showed that exposures of sperm and eggs of Crassostrea virginica to HEWAF, CEWAF, or dispersant significantly reduced fertilization in a dosedependent manner. Our study showed that mechanically mixed water accommodated fractions (HEWAF) reduced the fertilization success in a dose-dependent way, with an EC20 $1 \mathrm{~h}$ value reaching $1650 \mu \mathrm{g}$ tPAH50 $\mathrm{L}^{-1}$. The high-energy preparation (HEWAF) method might be a good surrogate for oil slicks subject to currents, wind, and waves, as demonstrated by Incardona et al. (2013), with an EC50 $1 \mathrm{~h}$ value reaching $2250 \mu \mathrm{g}$ tPAH50 L-1 (equivalent to a nominal dose of $\approx 1400 \mathrm{mg}$ DWH oil L ${ }^{-1}$ ). In the same way, Renzoni (1975) found that, after exposing $C$. virginica sperm and eggs separately to crude oils prepared in a similar way to the HEWAF for an hour before fertilization, fertilization success was depressed in a dosedependent way, with fertilization success falling to $\approx 68 \%( \pm 5)$ at nominal concentration of $1000 \mathrm{mg}$ oil $\mathrm{L}^{-1}$.

After adding Corexit $9500 \mathrm{~A}^{\circledR}$ to the DWH oil, concentrations of CEWAF that inhibited fertilization success were relatively low, with EC20 $1 \mathrm{~h}$ reaching $19.4 \mu \mathrm{g}$ tPAH50 L ${ }^{-1}$. Lowest observed effective concentration (LOEC) and effective concentration (ECx) results indicated that fertilization success followed similar trends after exposure to CEWAF or dispersant only. Consequently, one can suggest that most of the toxic effect induced by the dispersed oil can be attributed to the dispersant fraction of the CEWAF (i.e., 1:10). Toxicity of Corexit dispersants on the fertilization success of marine invertebrates has long been reported (Hagström and Lonning, 1977; Law, 1995). Negri and Heyward (2000) found that by dispersing oil chemically using Corexit 9527, fertilization capabilities were significantly reduced for coral species. However, it can become challenging to dissociate the contribution of dispersant from the toxic action of PAHs; as a consequence, an interactive/synergistic action of PAHs on the fertilization process following chemical dispersion must not be ruled out. According to Jeong and Cho (2005), movements of sperm cells from Crassostrea gigas were greatly affected upon exposure to 10 individual PAHs at concentrations as low as $50 \mu \mathrm{g}$ 
$1 \mathrm{~L}^{-1}$ ), with viability and motility significantly decreased with increasing concentrations of

2 PAHs (from 50 to $200 \mu \mathrm{g} \mathrm{L}^{-1}$ ). As a result, the inhibition of gamete fertilization observed in

3 the present study could be explained by a potential direct effect of dispersant and oil/PAHs

4 on the swimming behavior of the sperm cells and a decrease in the rate of collision between

5 eggs and spermatozoa, as Lewis et al. (2008) showed with a polychæte species, Arenicola

6 marina, exposed to crude oil.

7 Our results are consistent with those of Donaghy et al. (2012), who found that exposure of

8 C. virginica sperm to HEWAF, CEWAF, or Corexit $9500 \mathrm{~A}^{\circledR}$ had detrimental effects on

9 cellular mechanisms that are potentially involved in fertilization processes. Donaghy et al.

10 (2012) observed morphological modification of sperm cells, such as changing size and

11 increased internal complexity with increasing oil concentrations, alteration of acrosomal integrity, and inhibition of intracellular ROS production and mitochondrial metabolism. The physiological impairment of sperm cells could affect their motility and hence reduce their fertilization capabilities. In the same way, the spermiotoxicity of the herbicide Diuron ${ }^{\circledR}$ on C. gigas sperm induced an oxidative stress and affected directly intracellular ATP content, potentially reducing the motility of sperm cells (Akcha et al., 2012), but fertilization success was not measured concomitantly.

\subsection{Effects on embryogenesis}

Sensitive and drastic physiological processes occur during embryogenesis. For instance, shell formation begins early in embryogenesis through the secretion of the very first shell material by shell field epithelial cells (Eyster and Morse, 1984). Our results indicated that continuous exposure of gametes from pre-fertilization until 24-h post-fertilization to HEWAF, CEWAF, or Corexit $9500 \mathrm{~A}^{\circledR}$ negatively affected embryogenesis in a dose-dependent manner. Exposed gametes produced fewer embryos, and those embryos had higher percentages of morphological abnormalities than the control treatments. Similarly, continuous exposure of newly segmented embryos for $24 \mathrm{~h}$ to HEWAF, CEWAF, and dispersant adversely affected embryonic development, suggesting that both oil and dispersant may impair the mechanisms involved in shell secretion. Similar results were reported on C. gigas embryos contaminated with Alaskan crude oil, which led to severe abnormalities, such as deformed and incomplete shells, with an EC5048h value of $1000 \mathrm{ppm}$ or $1 \mathrm{ml} \mathrm{L}^{-1}$ (Le Gore, 1974). In a similar way, Le Pennec and Le Roux (1979) showed that the exposure of early developing embryos to a 
1 different type of crude oil for only $1 \mathrm{~h}$ induced high instances of shell abnormalities in

2 Mytilus edulis larvae, which exhibited both severe modifications of the hinge and

3 crystallization of the shell. Because morphological effects of CEWAF, HEWAF, and Corexit

4 were only apparent after $24 \mathrm{~h}$ of exposure in the present work, it appears that calcification

5 during oyster embryogenesis is one of the processes most sensitive to oil and dispersant.

6 Hayakaze and Tanabe (1999) revealed that the organic matrix of the mussel Mytilus

7 galloprovincialis shell began to be secreted by the shell gland during the late trocophore

8 larval stage ( $\approx 12 \mathrm{~h}$ post-fertilization), and calcification was localized on the inner side of the organic matrix in the early veliger stage. The early veliger calcification follows the same process in the European flat oyster, Ostrea edulis (Waller, 1981). Other aspects, such as protein synthesis and metabolism, require further investigation. Oil, PAHs, or the dispersant itself could also interfere and inhibit certain enzymatic activities; this has already been reported with oyster embryos exposed to heavy metals, such as the effects on carbonic anhydrase, which is involved in shell formation and calcium-transport pathways (Hinkle et al., 1987). Finally, Wessel et al. (2007) stated that the exposure of $C$. gigas embryos to the PAH benzo[ $\alpha]$ pyrene $(\mathrm{BaP})$ could cause high rates of abnormal larvae and DNA strand breakage.

Overall, there were few significant differences in the percentage of abnormalities between the larvae that were exposed at pre- or post-fertilization stages to HEWAF, CEWAF, and Corexit. These results suggest that negative effects of PAH and dispersant on early larval development mainly occurred during embryogenesis. This finding contradicts results reported by Geffard et al. (2001), who found that larvae derived from C. gigas embryos (postfertilization) exposed to PAH-polluted sediment exhibited more developmental abnormalities than larvae derived from exposed sperm (pre-fertilization). However, these authors exposed only sperm to PAHs, while in the present study both oocytes and sperm were exposed simultaneously, which could cause further damage to subsequent embryogenesis. From this, one may speculate that oocyte exposure to oil/PAHs and dispersant may be more likely to result in abnormal embryonic development than sperm exposure.

\subsection{Effects on larval shell lengths}

In addition to the significant effects of oil/PAHs and Corexit $9500 \mathrm{~A}^{\circledR}$ on Crassostrea virginica developmental success, HEWAF, CEWAF, or dispersant can subsequently inhibit shell growth. Shell lengths were significantly smaller for larvae reared in exposure solutions 
compared to the control. As mentioned previously, PAHs released from oil preparations as well as dispersant chemical compounds can disrupt normal embryogenesis, particularly shell formation, resulting in the reduction or inhibition of larval shell growth. Our results also demonstrated that levels of tPAH50 as low as $1.3 \mu \mathrm{g} \mathrm{L}^{-1}$ affected negatively the growth of larvae after $24 \mathrm{~h}$ exposure to CEWAF (Fig. 5C), a concentration of PAHs lower than that caused appreciable larval abnormality $\left(\mathrm{EC} 20_{24 \mathrm{~h}}=9.7 \mu \mathrm{g}\right.$ tPAH50 $\left.\mathrm{L}^{-1}\right)$. This finding suggests that larval growth is a sensitive and valid indicator of the toxicity of oil and dispersant. Hidu (1965), His and Robert (1985), and Geffard et al. (2002b) all showed that the larval growth assay with oysters was more sensitive than the embryo assay, using abnormality as endpoint. A marked reduction in larval growth may increase chances of death by predation or other factors (Calabrese et al., 1973; Davis and Hidu, 1969). Moreover, Strathman and Hart (1987, $1995)$ postulated that smaller larvae encounter and clear less food than larger larvae, and are therefore more prone to starvation. Hence, oil and dispersant may reduce the fitness of the affected larvae by reducing feeding efficiency, even if the concentrations they are exposed to are not lethal. Oil droplets resulting from dispersion could also have a negative physical effect, such as clogging the gills, binding to the velum (Anderson et al., 1974; Renzoni, 1975; Sigler and Leibovitz, 1982) or inhibiting respiration by coating membranes, particularly during HEWAF exposure. It is hypothesized that these droplets may also aggregate with algal cells (Muschenheim and Lee, 2002). This may significantly reduce food availability such as increasing the size of particles, flocculation, and emulsification; and affect filtration rates of larvae, resulting in starvation and death. To address this issue, it would be interesting to monitor additional endpoints such as swimming activity and feeding behavior, to get a more complete and sensitive approach.

\subsection{Effects on larval survival}

Preliminary range-finding experiments showed that DWH oil, prepared as low-energy WAF (LEWAF or WAF), had little effect on the survival of early stages of oysters, with LOEC values ranging from 11.7 to $25 \mu \mathrm{g}$ tPAH50 L-1 (equivalent to 1000 to $2000 \mathrm{mg} \mathrm{oil} \mathrm{L}^{-1}$ ) (data not shown). However, following exposure to mechanically dispersed DWH oil (HEWAF), larval survival was reduced by 50\% from 220 to $307 \mu \mathrm{g}$ tPAH50 L-1 (equivalent to 130 to 184 $\mathrm{mg}$ oil $\mathrm{L}^{-1}$ ). In light of these results, the high-energy preparation (HEWAF) method seems to be a good surrogate for oil slicks subject to the action of current, wind, and waves, as 
1 demonstrated by Incardona et al. (2013). Moreover, concentrations of CEWAF and Corexit that inhibited larval survival by $50 \%$ were relatively low, i.e. 8.5 to $17.7 \mu \mathrm{g}$ tPAH50 L-1

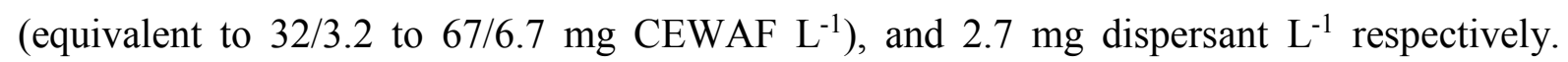
Various studies found that, compared to oil alone (WAF), the addition of Corexit $9500 \mathrm{~A}^{\circledR}$ to oil (CEWAF) decreased survival during exposure of amphipods (Gulec et al., 1997), copepods (Lee et al., 2013), mussels and sea urchins (Saco-Alvarez et al., 2008), and coral species (Negri and Heyward, 2000). Similarly, Rico-Martinez et al. (2013) indicated that the addition of Corexit $9500 \mathrm{~A}^{\circledR}$ to Macondo oil (or DWH oil) at a ratio realistically encountered in the Gulf at the time of the spill (1:10), increased toxicity to the rotifer Brachionus plicatilis by 52-fold compared to LEWAF. It cannot be excluded that the increased toxicity observed in these studies could be mainly attributed to dispersant alone. However, at the highest nominal doses tested in the present study (above $50 \mathrm{mg}$ oil $\mathrm{L}^{-1}$ and $5 \mathrm{mg}$ dispersant $\mathrm{L}^{-1}$ ), CEWAF exposure resulted in a higher percentage of abnormal larvae than with Corexit alone (at $5 \mathrm{mg} \mathrm{L}^{-1}$ ) (Fig. 3B and C).

According to the U.S. National Research Council (1989), the acute lethal toxicity of chemically dispersed oil resides not only in the dispersant but primarily in the bioavailability of oil droplets (for some species) and the low molecular weight and dissolved aromatic fractions of the oil (for most species). Apart from larval abnormalities observed at the highest doses of CEWAF previously mentioned, the present study did not demonstrate an exacerbated effect of CEWAF on larval survival compared to Corexit 9500A alone. In fact, at equivalent nominal doses tested, our results demonstrated that in most cases, CEWAF was even less toxic than dispersant alone (Table 4). Fucik (1994) reported similar results with eastern oyster embryos that he exposed to Corexit 9527A alone or mixed with Gulf of Mexico crude oil, with nominal LC50 of $4.9 \mathrm{mg} \mathrm{L}^{-1}$ and $11.2 \mathrm{mg}$ CEWAF L $^{-1}$ respectively. This finding suggests that most of the toxic effect of the dispersed oil is likely imputable to some of the chemical characteristics of the Corexit. Because of the DOSS compound and its surfactant properties (NALCO, 2012), dispersant can break down oil into very small particles (NRC, 2005), which may make oil droplets more likely to affect filter-feeding organisms like eastern oyster larvae through ingestion or by clogging of the gills. Additionally, the acute toxicity of dispersant alone is usually attributed to its surface-active effect on bio membranes, including the disruption of respiratory cells resulting from electrolytic and osmotic imbalances (Abel, 1974; Singer et al., 1991, 1996). Accordingly, microscopic observations of organisms in 96-h samples of the present study exhibited severe damages, such as membrane 
1 rupture, "explosion" of cells, and extrusion of larval tissues, which could be attributed to the 2 dispersant. Overall, it can become challenging to dissociate the contribution of dispersant 3 from the toxic action of PAHs; as a consequence, an interactive/synergistic action of PAHs on the embryogenesis process following chemical dispersion must not be ruled out. Thus, caution should be used when deciding to use chemical dispersion as a remedial action for an oil spill, especially in a coastal marine environment.

Overall, our results demonstrated a stage-dependent response to CEWAF, with PAH and dispersant inducing more retardation of growth and more mortality in larvae derived from exposed gametes than embryos. However, long-term exposure to HEWAF (96 h) seemed to affect further growth and survival of larvae derived from exposed embryos than gametes. This difference of stage sensitivity to HEWAF may be caused by a high variability between treatments. Perhaps the exposure to droplet-associated PAHs contained in the HEWAF may be more toxic to embryos than sperm and oocytes. To answer this question, additional research on the toxicity related to the dissolved and particulate fraction of HEWAF, and particularly on the interaction of these droplets with various life stages of oysters, is needed.

The purpose of this study was to determine lethal and effective concentrations on different life stages of oysters. From these data, it is now possible to compare our findings with fieldcollected data and predict acute effects likely to occur to eastern oysters as well as other filter-feeding species in field situations and improve the management of water quality of coastal zones worldwide. It is important to note that, in the natural environment, the toxicity of crude oil not only depends on the concentrations of oil and the duration of exposure but also on environmental conditions. As a result, the impact of accidental oil spills on early life stages of oysters will vary depending on the specific circumstances of each catastrophe. For instance, a factor that we did not consider in this study is photo-induced toxicity. Ultraviolet radiation may increase the toxicity of petroleum hydrocarbons (e.g., PAHs) on exposed marine organisms, including oysters (Landrum et al., 1987; Lyons et al., 2002; Pelletier et al., 1997). Although speculation and extrapolation of laboratory findings to the field need to be taken cautiously, experimental studies are a reliable way of determining major toxic effects of hydrocarbons on sensitive aquatic organisms such as oyster larvae.

Harmful effects of PAHs on marine organisms including bivalves such as oysters have long been documented (Geffard et al., 2002b, 2003; Jeong and Cho, 2005; Lyons et al., 2002; Pelletier et al., 2000; Wessel et al., 2007). The present study provided evidence that oil released during the DWH explosion, and particularly the application of dispersants, can 
seriously impair the early development of the eastern oyster, even at very low concentrations. Oil spills could pose long-term effects on aquatic animals and their ecosystem. Oyster larvae may bio-accumulate various PAHs (especially those with high molecular weights) by ingestion through the filtration of previously dispersed oil micelles, as shown in other zooplankton species (Almeda et al., 2013; Lee et al., 2013). Thus, further research needs to be done on the potential for PAHs to bio-accumulate in bivalve larvae.

\section{Summary}

The present study determined the potential effects of the DWH oil spill and the application of dispersant to treat oil slicks on early life stages of the eastern oyster via short-term exposure experiments. Results revealed that the exposure of oyster gametes and embryos to oil preparations and dispersant impaired fertilization success, the normal development of embryos to the larval stage, and the growth of the resulting larvae. It also induced larval death, with dispersed oil and dispersant alone producing the highest impact. These results suggest that oil spills and employing dispersants to disperse oil at the time of the oyster spawning season could affect oyster recruitment and, ultimately, oyster resources in affected regions.

\section{Acknowledgements}

This work was supported by funds provided as part of the natural resource damage assessment for the Deepwater Horizon oil spill. Data presented here are a subset of a larger toxicological database that is being generated as part of the Deepwater Horizon Natural Resource Damage Assessment. We also would like to thank the graduate students and staff at the Vester Field Station, especially Brooke Denkert, Jeffrey Devine, Vaiola Osne, Anne Rolton, Molly Rybovich, Andy Griffith, and Gaelle Richard for their technical assistance.

\section{References}

Abel, P. D. (1974). Toxicity of synthetic detergents to fish and aquatic invertebrates. Journal of fish Biology, 6(3), 279-298.

Akcha, F., Spagnol C., \& Rouxel J. (2012). Genotoxicity of diuron and glyphosate in oyster spermatozoa and embryos. Aquatic Toxicology, 106: 104-113 
Albers, P. H. and Loughlin, T. R. (2003). Effects of PAHs on marine birds, mammals and reptiles. PAHs: An Ecotoxicological Perspective: 243-261.

Allen, T. E. (1984). Oil Spill Chemical Dispersants: Research, Experience, and Recommendations: a Symposium, ASTM International.

Almeda, R., Wambaugh, Z., Wang, Z., Hyatt, C., Liu, Z., \& Buskey, E. J. (2013). Interactions between zooplankton and crude oil: toxic effects and bioaccumulation of polycyclic aromatic hydrocarbons. PloS one, 8(6), e67212.

Anderson, J. W., Neff, J. M., Cox, B. A., Tatem, H. E., \& Hightower, G. M. (1974). Characteristics of dispersions and water-soluble extracts of crude and refined oils and their toxicity to estuarine crustaceans and fish. Marine Biology, 27(1), 75-88.

Barron, M. G., Podrabsky, T., Ogle, S., \& Ricker, R. W. (1999). Are aromatic hydrocarbons the primary determinant of petroleum toxicity to aquatic organisms? Aquatic Toxicology, 46(3), 253-268.

Barron, M. G., Carls, M. G., Short, J. W., \& Rice, S. D. (2003). Photoenhanced toxicity of aqueous phase and chemically dispersed weathered Alaska North Slope crude oil to Pacific herring eggs and larvae. Environmental Toxicology and Chemistry, 22(3), 650-660.

Beiras, R. and His, E. (1994). Effects of dissolved mercury on embryogenesis, survival, growth and metamorphosis of Crassostrea gigas oyster larvae. Marine Ecology Progress Series 113: 95-103.

Bolker, B. and R Development Core Team. (2013). bbmle: Tools for General Maximum Likelihood Estimation. R package Version 1.0.17. Available: http://CRAN.Rproject.org/package $=$ bbmle

Calabrese, A., Collier, R. S., Nelson, D. A., \& MacInnes, J. R. (1973). The toxicity of heavy metals to embryos of the American oyster Crassostrea virginica. Marine Biology, 18(3), 162-166.

Canevari, G. P. (1973). Development of the next generation chemical dispersants. Proceedings of Joint Conference on Prevention and Control of Oil Spills.

Capuzzo, J. M. (1996). The bioaccumulation and biological effects of lipophilic organic contaminants. The Eastern Oyster, Crassostrea virginica. MD Sea Grant Publication: 539-557.

Chapman, P. M. and Long, E. R. (1983). The use of bioassays as part of a comprehensive approach to marine pollution assessment. Marine Pollution Bulletin, 14(3), 81-84.

Chapman, G. (1989): Pacific oyster, Crassostrea gigas, and Mussel, Mytilus sp, embryo-larval development test method. ASTM Committee, Section 13

Coen, L. D., Brumbaugh, R. D., Bushek, D., Grizzle, R., Luckenbach, M. W., Posey, M. H., Powers, S. P. \& Tolley, G. S. (2007). Ecosystem services related to oyster restoration. Marine Ecology Progress Series, 341, 303-307.

Connor, P. M. (1972). Acute toxicity of heavy metals to some marine larvae. Marine Pollution Bulletin, 3(12), 190-192.

Couillard, C. M., Lee, K., Légaré, B., \& King, T. L. (2005). Effect of dispersant on the composition of the water-accommodated fraction of crude oil and its toxicity to larval marine fish. Environmental toxicology and chemistry, 24(6), 1496-1504. 

leak. Science, 330(6004), 634-634.

Cucci, T. L. and Epifanio, C. E. (1979). "Long-term effects of water-soluble fractions of Kuwait crude oil on the larval and juvenile development of the mud crab Eurypanopeus depressus." Marine Biology, 55(3), 215-220.

Davis, H. C. and Hidu H. (1969). Effects of pesticides on embryonic development of clams and oysters and on survival and growth of the larvae. Fisheries Bulletin $267(2), 393-404$.

Davis, P. H., Schultz, T. W., \& Spies, R. B. (1981). Toxicity of Santa Barbara seep oil to starfish embryos: Part 2 - the growth bioassay. Marine environmental research, 5(4), 287-294.

Donaghy, L., Vignier, J., Denkert, B., Devine, J., Haynes, L., Soudant, P., Chu, F.L.E, Morris, J.M., Carney, M.W, Lipton, J. \& Volety, A. K. (2012, November) "Impact of the Deepwater Horizon oil spill on the eastern oyster, Crassostrea virginica, reproductive output: from spermatozoa cellular alterations to unsuccessful fertilization". SETAC 2012, Long Beach, CA.

Eyster, L. S. and M. P. Morse (1984). Early shell formation during molluscan embryogenesis, with new studies on the surf clam, Spisula solidissima. American zoologist 24(4): 871-882.

Faraggi, D., Izikson, P., \& Reiser, B. (2003). Confidence intervals for the 50 per cent response dose. Statistics in Medicine 22:1977-1988.

Fucik, K. (1994). Dispersed oil toxicity tests with species indigenous to the Gulf of Mexico. OCS reports. U. S. Minerals Management Service(94).

Galtsoff, P. S. (1964). The American oyster, Crassostrea virginica (Gmelin). Fishery Bulletin 64: 1480 .

Geffard, O., Budzinski, H., Augagneur, S., Seaman, M. N., \& His, E. (2001). Assessment of sediment contamination by spermiotoxicity and embryotoxicity bioassays with sea urchins (Paracentrotus lividus) and oysters (Crassostrea gigas). Environmental toxicology and chemistry, 20(7), 1605-1611.

Geffard, O., Budzinski, H., \& His, E. (2002b). The effects of elutriates from PAH and heavy metal polluted sediments on Crassostrea gigas (Thunberg) embryogenesis, larval growth and bioaccumulation by the larvae of pollutants from sedimentary origin. Ecotoxicology, 11(6), 403-416.

Geffard, O., Geffard, A., His, E., \& Budzinski, H. (2003). Assessment of the bioavailability and toxicity of sediment-associated polycyclic aromatic hydrocarbons and heavy metals applied to Crassostrea gigas embryos and larvae. Marine Pollution Bulletin, 46(4), 481-490.

Getter, C. D. and Baca, B. J. (1984). A laboratory approach for determining the effect of oils and dispersants on mangroves. Oil Spill Chemical Dispersants. Research, Experience, and Recommendations, STP 840: 5-13.

Gulec, I., Leonard, B., \& Holdway, D. A. (1997). Oil and dispersed oil toxicity to amphipods and snails. Spill Science \& Technology Bulletin, 4(1), 1-6.

Hagström, B. E. and Lönning, S. (1977). The effects of Esso Corexit 9527 on the fertilizing capacity of spermatozoa. Marine Pollution Bulletin 8(6): 136-138.

Hart, M. W. and Strathmann, R. R. (1995). Mechanisms and rates of suspension feeding. CRC Marine Science Series, 6. 
Hayakaze, E. and Tanabe, K. (1999). Early larval shell development in mytilid bivalve Mytilus galloprovincialis. Venus, 58, 119-127.

Hidu, H. (1965). Effects of synthetic surfactants on the larvae of clams (M. mercenaria) and oysters (C. virginica). Journal (Water Pollution Control Federation), 262-270.

Hinkle, P. M., Kinsella, P. A., \& Osterhoudt, K. C. (1987). Cadmium uptake and toxicity via voltagesensitive calcium channels. Journal of Biological Chemistry, 262(34), 16333-16337.

His, E. and Robert, R. (1983). Development of Crassostrea gigas larvae in the Bay of Arcachon: Study on the larval mortality. Rev. Trav. Inst. Peches. Marit., 47(1-2): 63-88.

His, E. and Robert, R. (1985). Utilisation des élevages larvaires de Crassostrea gigas en écotoxicologie marine. VI Congrès de la Société Française de Malacologie et Colloque «Contamination, intoxication et perturbation des mollusques marins ». Haliotis, $15: 301-308$

His, E., Seaman, M. N. L., Beiras, R. (1997). A simplification of the bivalve embryogenesis and larval development bioassay method for water quality assessment. Water Research, 31(2): 351-355.

His, E. and Beiras R. (1999). The assessment of marine pollution-bioassays with bivalve embryos and larvae. Advances in Marine Biology 37: 1.

Huffman Ringwood, A. (1991). Short-term accumulation of cadmium by embryos, larvae, and adults of an Hawaiian bivalve, Isognomon californicum. Journal of experimental marine biology and ecology 149(1): 55-66.

Incardona, J. P., Swarts, T. L., Edmunds, R. C., Linbo, T. L., Aquilina-Beck, A., Sloan, C. A., Gardner, L. D., Block, B. A.. \& Scholz, N. L. (2013). Exxon Valdez to Deepwater Horizon: Comparable toxicity of both crude oils to fish early life stages. Aquatic Toxicology, 142: 303-316.

Ingle, R.M. (1951). Spawning and setting of oysters in relation to seasonal environmental changes. Bull. Mar. Sci. Gulf Carib. 1: 111-135

Jeong, W. G. and Cho, M. S. (2005). The effects of polycyclic aromatic hydrocarbon exposure on the fertilization and larval development of the Pacific oyster, Crassostrea gigas. Journal of Shellfish Research, 24(1): 209-213.

Kujawinski, E. B., Kido Soule, M. C., Valentine, D. L., Boysen, A. K., Longnecker, K., \& Redmond, M. C. (2011). Fate of dispersants associated with the Deepwater Horizon oil spill. Environmental science \& technology, 45(4), 1298-1306.

Landrum, P. F., Giesy, J. P., Oris, J. T., \& Allred, P. M. (1987). Photoinduced toxicity of polycyclic aromatic hydrocarbons to aquatic organisms. Oil in freshwater: chemistry, biology, countermeasure technology. Elmsford, NY: Pergamon Press: 304-318.

Laramore, S., Krebs, W., \& Garr, A. (2014). Effects of Macondo Canyon 252 Oil (Naturally and Chemically Dispersed) on larval Crassostrea virginica (Gmelin, 1791). Journal of Shellfish Research, 33(3), 709-718.

Law A. L. (1995). Toxicity study of the oil dispersant COREXIT 9527 on Macrobrachium rosenbergii (de Man) egg hatchability by using a flow-through bioassay technique. Environmental Pollution 88: 341-343

Lee, K. W., Shim, W. J., Yim, U. H., \& Kang, J. H. (2013). Acute and chronic toxicity study of the water accommodated fraction (WAF), chemically enhanced WAF (CEWAF) of crude oil and 
40

dispersant in the rock pool copepod Tigriopus japonicus. Chemosphere.

http://dx.doi.org/10.1016/j.chemosphere.2013.01.080

Le Gore, R. S. (1974). The effect of Alaskan crude oil and selected hydrocarbon compounds on embryonic development of the Pacific oyster, Crassostrea gigas [Ph. D. Thesis].

Le Pennec, L. et Le Roux S. (1979). Effets d'un pétrole brut sur la formation de la coquille de Mytilus edulis (L.)(Mytilidae, Bivalvia). Rev. int. Océanogr. Méd, 55, 49-55.

Lessard, R. R. and DeMarco, G. (2000). The significance of oil spill dispersants. Spill Science \& Technology Bulletin 6(1): 59-68.

Lewis, C., Pook, C., and Galloway, T. (2008). Reproductive toxicity of the water accommodated fraction (WAF) of crude oil in the polychaetes Arenicola marina (L.) and Nereis virens (Sars). Aquatic Toxicology, 90(1), 73-81.

Li, M. and Garrett, C. (1998). The relationship between oil droplet size and upper ocean turbulence. Marine Pollution Bulletin, 36(12): 961-970.

Lyons, B. P., Pascoe, C. K., \& McFadzen, I. R. B (2002). Phototoxicity of pyrene and benzo [a] pyrene to embryo-larval stages of the pacific oyster Crassostrea gigas. Marine environmental research 54(3): 627-631.

McDowell, J. E., Lancaster, B. A., Leavitt, D. F., Rantamaki, P., \& Ripley, B. (1999). The effects of lipophilic organic contaminants on reproductive physiology and disease processes in marine bivalve molluscs. Limnology and Oceanography, 44(3), 903-909.

McNutt, M. K., Camilli, R., Crone, T. J., Guthrie, G. D., Hsieh, P. A., Ryerson, T. B., Savas, O. \& Shaffer, F. (2012). Review of flow rate estimates of the Deepwater Horizon oil spill. Proceedings of the National Academy of Sciences, 109(50), 20260-20267.

Muschenheim, D. K. and Lee, K. (2002). Removal of oil from the sea surface through particulate interactions: review and prospectus. Spill Science \& Technology Bulletin, 8(1), 9-18.

Nalco Energy Services (2012). Material Safety Data Sheet for Corexit 9500A ${ }^{\circledR}$. http://www.nalcoesllc.com/nes/documents/MSDS/NES-LLC-COREXIT-EC9500A-March_2012.pdf (last consulted on August $10^{\text {th }} 2013$ )

National Marine Fisheries Service, (2012). Annual Commercial Landing Statistics, Fisheries Statistics. Available at http://www.st.nmfs.noaa.gov/st1/commercial/landings/annual landings.html (last consulted in July 2014)

National Commission on the BP Deep Ocean Horizon Oil Spill and Offshore Drilling. (2011). Deep water: The Gulf oil disaster and the future of offshore drilling. Report to the President. www.oilspillcommission.gov. Accessed on September 2011

National Research Council, (1989). Using Oil Spill Dispersants on the Sea. National Academy Press, Washington, DC. Chapter 3.

National Research Council (U.S), (2005). Committee on Understanding Oil Spill Dispersants: Efficacy and Effects. Oil Spill Dispersants: Efficacy and Effects. Washington, DC: The National Academies Press 
Neff, J. M. (1985). Polycyclic aromatic hydrocarbons. Fundamentals of Aquatic Toxicology: Methods and Applications. Hemisphere Publishing Corporation Washington DC. 1985. p 416-454, 2 fig, 7 tab, 140 ref.

Neff, J.M. (1987). Biological effects of drilling fluids, drill cuttings and produced waters (pp. 469538). Elsevier Applied Science, London, United Kingdom.

Negri, A. P., and Heyward, A. J. (2000). Inhibition of Fertilization and Larval Metamorphosis of the Coral, Acropora millepora (Ehrenberg, 1834) by Petroleum Products. Marine Pollution Bulletin, 41(7), 420-427.

Newell, R. I. (2004). Ecosystem influences of natural and cultivated populations of suspensionfeeding bivalve molluscs: A review. Journal of Shellfish Research. 23(1): 51-62.

Page, C. A., Bonner, J. S., Sumner, P. L., McDonald, T. J., Autenrieth, R. L., \& Fuller, C. B. (2000). Behavior of a chemically-dispersed oil and a whole oil on a near-shore environment. Water Research, 34(9), 2507-2516.

Pelletier, M. C., Burgess, R. M., Ho, K. T., Kuhn, A., McKinney, R. A., \& Ryba, S. A. (1997). Phototoxicity of individual polycyclic aromatic hydrocarbons and petroleum to marine invertebrate larvae and juveniles. Environmental toxicology and chemistry, 16(10), 2190-2199.

Pelletier, M. C., Burgess, R. M., Cantwell, M. G., Serbst, J. R., Ho, K. T., \& Ryba, S. A. (2000). Importance of maternal transfer of the photoreactive polycyclic aromatic hydrocarbon fluoranthene from benthic adult bivalves to their pelagic larvae. Environmental toxicology and chemistry, 19(11), 2691-2698.

Peterson, C. H., Grabowski, J. H., \& Powers, S. P. (2003). Estimated enhancement of fish production resulting from restoring oyster reef habitat: quantitative valuation. Marine Ecology Progress Series, 264, 249-264.

R Development Core Team. (2014). The R Project for Statistical Computing. R Foundation for Statistical Computing, Vienna, Austria. Available: http://www.R-project.org/.

Ramachandran, S. D., Hodson, P. V., Khan, C. W., \& Lee, K. (2004). Oil dispersant increases PAH uptake by fish exposed to crude oil. Ecotoxicology and environmental safety, 59(3), 300-308.

Renzoni, A. (1975). Toxicity of three oils to bivalve gametes and larvae. Marine Pollution Bulletin, 6(8): 125.

Rico-Martínez, R., Snell, T. W., \& Shearer, T. L. (2013). Synergistic toxicity of Macondo crude oil and dispersant Corexit $9500 \mathrm{~A}^{\circledR}$ to the Brachionus plicatilis species complex (Rotifera). Environmental Pollution, 173, 5-10.

Ritz, C. (2010). Toward a unified approach to dose-response modeling in ecotoxicology. Environmental Toxicology and Chemistry 29(1):220-229.

Ritz, C. and Streibig, J. C. (2005). Bioassay analysis using R. Journal of Statistical Software 12(5).

Roesijadi, G., Anderson, J. W., \& Blaylock, J. W (1978). Uptake of hydrocarbons from marine sediments contaminated with Prudhoe Bay crude oil: Influence of feeding type of test species and availability of polycyclic aromatic hydrocarbons. Journal of the Fisheries Board of Canada, 35(5): 608-614. 
Rosenbauer, R. J., Campbell, P. L., Lam, A., Lorenson, T. D., Hostettler, F. D., Thomas, B., \& Wong, F. L. (2010). Reconnaissance of Macondo-1 well oil in sediment and tarballs from the Northern Gulf of Mexico shoreline, Texas to Florida. U. S. Geological Survey.

Rossi, S. S., Anderson, J. W., \& Ward, G. S (1976). Toxicity of water-soluble fractions of four test oils for the polychaetous annelids, Neanthes arenaceodentata and Capitella capitata. Environmental Pollution 10(1): 9-18.

Saco-Álvarez, L., Bellas, J., Nieto, Ó., Bayona, J. M., Albaigés, J., \& Beiras, R. (2008). Toxicity and phototoxicity of water-accommodated fraction obtained from Prestige fuel oil and marine fuel oil evaluated by marine bioassays. Science of the total environment, 394(2), 275-282.

Sigler, M. and Leibovitz, L. (1982). Acute toxicity of oil and bilge cleaners to larval American oysters (Crassostrea virginica). Bulletin of environmental contamination and toxicology, 29(2), 137-145.

Singer, M. M., Smalheer, D. L., Tjeerdema, R. S., \& Martin, M. (1991). Effects of spiked exposure to an oil dispersant on the early life stages of four marine species. Environmental toxicology and chemistry, 10(10), 1367-1374.

Singer, M. M., George, S., Jacobson, S., Lee, I., Weetman, L. L., Tjeerdema, R. S., \& Sowby, M. L. (1996). Comparison of acute aquatic effects of the oil dispersant Corexit 9500 with those of other Corexit series dispersants. Ecotoxicology and Environmental Safety, 35(2), 183-189.

Strathmann, R. R. (1987). Larval feeding. Reproduction of marine invertebrates, 9, 465-550.

Thain, J. E. (1991). Biological effects of contaminants: oyster (Crassostrea gigas) embryo bioassay. Copenhagen, Denmark: ICES.

Thain, J. E. (1992). Use of the oyster Crassostrea gigas embryo bioassay on water and sediment elutriate samples from the German Bight. Marine ecology progress series. Oldendorf, 91(1), 211-213.

Thompson, P. A., Guo, M. X., \& Harrison, P. J. (1996). Nutritional value of diets that vary in fatty acid composition for larval Pacific oysters (Crassostrea gigas). Aquaculture, 143(3), 379-391.

U.S. EPA. (1996). Ecological Effects Test Guidelines: OPPTS 850.1055: Bivalve Acute Toxicity Test (embryo larval)"

U.S. EPA. (2013). Benchmark Dose Software (BMDS). Version 2.4 R70 [Build: 04/01/2013].U.S. Environmental Protection Agency, National Center for Environmental Assessment. Available: http://www.epa.gov/NCEA/bmds/index.html.

Utting, S. D. and Millican, P. F. (1997). Techniques for the hatchery conditioning of bivalve broodstock and the subsequent effect on egg quality and larval viability. Aquaculture 155(1): 45-54.

Venosa, A. D. and Zhu, X. (2003). Biodegradation of crude oil contaminating marine shorelines and freshwater wetlands. Spill Science \& Technology Bulletin 8(2): 163-178.

Venzon, D.J. and Moolgavkar. S. H. (1988). A method for computing profile-likelihood-based confidence intervals. Applied Statistics 37:87-94.

Volety, A. K., Haynes, L., Goodman, P. \& Gorman, P. (2014). Ecological condition and value of oyster reefs of the Southwest Florida shelf ecosystem. Ecological Indicators, http://dx.doi.org/10.1016/j.ecolind.2014.03.012 . 
1 Waller, T. R. (1981). Functional morphology and development of veliger larvae of the European oyster. Ostrea edulis, 1-70.

Wells, H.W. (1961). The fauna of oyster beds, with special reference to the salinity factor. Ecological Monographs. 31(3): 239-266.

Wessel, N., Rousseau, S., Caisey, X., Quiniou, F., \& Akcha, F. (2007). Investigating the relationship between embryotoxic and genotoxic effects of benzo $[a]$ pyrene, $17 \alpha$-ethinylestradiol and endosulfan on Crassostrea gigas embryos. Aquatic Toxicology, 85(2), 133-142.

Woelke, C. E. (1972). "Development of a receiving water quality bioassay criterion based on the 48hour Pacific oyster (Crassostrea gigas) embryo." Washington Department of Fisheries-Technical 13 Report 9. 